\title{
On the Numbering of Quires in the Christian Sogdian and Syriac Manuscript Fragments in the Turfan Collection (Berlin) and the Krotkov Collection (St. Petersburg) ${ }^{1}$
}

Abstract: The present contribution serves two purposes. First, it highlights the quire numbering system as reflected in the Christian Sogdian (in East Syriac script) and Syriac manuscript fragments from the Turfan Collection (Berlin) and the Krotkov Collection (St. Petersburg). The main aim of this part is to offer a tentative typology of the numbering of quires. It shows that not only the Syriac manuscript tradition of the Church of the East, but also the Christian Palestinian Aramaic manuscript tradition offers important clues for understanding this material. Second, this study inserts itself into a trajectory of Manuscript Studies that combines codicology and palaeography with history and cultural history in order to shed light on the social aspects of the production and consumption of manuscripts, and on the dissemination of particular technical aspects between Mesopotamia and Central Asia during late Antiquity and the early Middle Ages.

Key words: Manuscript Studies, Turfan manuscript fragments, eastern Christianity

\section{The Syriac manuscript tradition: structuring and numbering of the quires}

The more than 1000 Christian Sogdian and Syriac manuscript fragments preserved in the Berlin Turfan Collection constitute a chronologically and geographically coherent corpus. As I have argued elsewhere, ${ }^{2}$ it does not make sense to look at the Christian Sogdian manuscript tradition in isolation: like Christian Sogdian literature, it mostly belongs to the cultural religious

(C) Chiara Barbati, Institute of Iranian Studies, Austrian Academy of Sciences, Vienna (chiara.barbati@oeaw.ac.at)

${ }^{1}$ This article is part of my ongoing project "Scribal habits. A case study from Christian Medieval Central Asia" funded by the Austrian Science Fund (FWF).

I would like to express my deepest gratitude to Alain Desreumaux for many useful suggestions and improvements.

A special thank goes to Florian Schwarz for stimulating discussion on scribal discourse on a vast scale while writing this article.

${ }^{2}$ BARBATI 2015; BARBATI 2017. 
heritage of the Church of the East, and we cannot ignore this crucial point if we want to achieve a full comprehension of the material under investigation.

In 1946 Hatch wrote the following regarding the numbering of quires in Syriac manuscripts: "The quires were generally numbered with Syriac letters; but sometimes Syriac arithmetical figures or letters of the Greek, Coptic, or Arabic alphabets were employed for purpose (According to Wright, 1870-1872, p. xxvi, Syriac arithmetical figures were not in general use after the ninth century). The numeral was sometimes put at the end of the quire, and sometimes it was given both at the beginning and at the end. It was normally placed at the bottom of the page. Occasionally, however, Syriac letters were used at the bottom of the page and Greek letters at the top, and the running title was sometimes written at the top of the first and last pages of the quire. These advices were intended to aid the binder when he combined the quires to form a codex".

In the last decades, the growth of Manuscript Studies or "Manuscriptology" as field of research has also helped to revitalize interest in the Syriac manuscript tradition. With particular regard to the Syriac manuscript tradition, the most recent surveys on the disciplines that are considered to be part of Manuscript Studies (codicology, palaeography, interplay of textual and material aspects as well as on historical context, cataloguing, conservation and preservation) have been published in $2015 .^{4}$ In a chapter of a volume devoted to Syriac codicology, Borbone and Briquel-Chatonnet summarize the structuring and numbering of quires in the Syriac manuscript tradition as follows: "The structure of the quires in Syriac books is remarkably uniform and stable over time, for all geographical areas in which Syriac manuscripts were produced. They are mainly composed of quinions, both of parchment and of paper. The quires were made by stacking individual bifolia (usually five) and not by folding a sheet twice the size of a bifolium (or larger)". ${ }^{6}$ Quinions is also the quire structure postulated by Sims-Williams for the Christian fragments from Turfan. ${ }^{7}$

On the numbering of the quires, Borbone and Briquel-Chatonnet wrote: "Numbering of quires is standard in Syriac books. The numbers are written

\footnotetext{
${ }^{3}$ HATCH 1946, 23.

${ }^{4}$ BAUSI and BORBONE et al. 2015, 57-59, 252-266, 316-320, 411-414, 435-439, 502-503 and BRIQUEL-CHATONNET and DEBIÉ 2015.

${ }^{5}$ BORBONE and BRIQUEL-CHATONNET and BALICKA-WITAKOWSKA 2015.

${ }^{6}$ Borbone and BriQuel-CHATONNET and BALICKA-WITAKOWSKA 2015, 255.

${ }^{7}$ Sims-Williams 1985, 15.
} 
on the first and the last page of each quire, in the bottom margin. A quire number in the upper margin never occurs, nor do bifolium signatures. Very often, the first quire of a book bears no number at the beginning, because the recto of the first leaf is left blank; in Syriac manuscripts, the texts usually begins on the verso of the first leaf... numbering both the beginning and the end of a quire becomes standard practice, with placement of the number at the centre of the bottom margin...The script used for quire numbers very often changes, by alternating use of different Syriac scripts, serțā and 'estranghēlā. But exceptions do occur: for instance, London, BL, Add. 14548 (790), f. 33r, beginning of the fourth quire, shows the numeral $\mathrm{d}=4$, in 'estranghēlā script, written twice in the lower margin, once at the centre, and again to the right, the latter numeral being more prominently decorated (Tisserant 1914, xxiv and 28). Headings, or running titles, are seldom used, but they appear already in the oldest manuscripts, such as the Rabbula Gospel, where they are written in red in the top margin of the verso of the fifth leaf (i.e. at the central opening of a quinion). In other cases..., the rubricated headings are written in the top margin of all leaves on the recto. In this case they serve the needs of the reader, and were perhaps added after the copyist finished his work, either by him or by owners/users of the book". 8

Finally, from a theoretical point of view, this contribution shares the definition of a quire as given by Andrist, Canart, and Maniaci: "Nous proposons donc de définir le cahier comme "un ensemble de bifolios et/ou de folios emboités les uns dans les autres". 9 Or, taking up the English translation by Maniaci in a separate article: "The basic constitutive unit of the codex is the 'quire', or 'gathering', which may be defined as 'a series of bifolia and/or folia [leaves] inserted one into the other". ${ }^{10}$

\section{Quire numbering as attested in the Christian Sogdian and Syriac manuscript fragments belonging to the Berlin Turfan Collection}

The Christian Sogdian manuscript fragments in the Berlin Turfan Collection show that the quires are numbered with Syriac letters. According to Sims-Williams, ${ }^{11}$ we find quire-numbers in the following manuscript frag-

\footnotetext{
${ }^{8}$ BORBONE and BRIQUEL-CHATONNET and BALICKA-WITAKOWSKA 2015, 256.

${ }^{9}$ ANDRIST and CANART and MANIACI 2013, 50.

${ }^{10}$ MANIACI 2015, 8.

${ }^{11}$ Sims-WiLliams 2012, 237.
} 
ments: E5/41, E5/51, E5/91, E5/100, E5/101, E26/3, E26/22(?), E26/28, E26/43(?), E27/31, E27/51, E27/60, E27/61, E27/127, E28/12, E28/19, $\mathrm{E} 28 / 80, \mathrm{E} 28 / 90, \mathrm{E} 28 / 122, \mathrm{E} 29 / 5, \mathrm{E} 44$.

In the first catalogue of the Syriac manuscript fragments in the Turfan Collection, Hunter and Dickens make a list of the "technical aspects of fragments" quoting quire-numbers, among other things. According Hunter and Dickens quire-numbers are attested in the following fragments: SyrHT 72, SyrHT 76, SyrHT $81 \& 82$, SyrHT 85, SyrHT 123, SyrHT 125, SyrHT 145, SyrHT 156, SyrHT 191, SyrHT 194, SyrHT 195, SyrHT 231, SyrHT 300, SyrHT 307, SyrHT 325, SyrHT 327?, SyrHT 348?, n416? ${ }^{12}$

Instead of discussing the evidence of the quires in the above-mentioned order, we will group them according to specific similarities in order to establish a typology. ${ }^{13}$ It goes without saying that there clearly are limits since we are dealing with a very fragmentary manuscript tradition: not a single complete codex has survived. ${ }^{14}$ Methodologically speaking, how can we classify manuscript fragments as type $\mathrm{x}$ or type $\mathrm{y}$ if we have only few fragments or even a single fragment? Dealing with a very fragmentary manuscript tradition means that we must accept many limitations ${ }^{15}$ and to avoid establishing a general theory or explanation. Nevertheless — as demonstrated by studies conducted on more well-established fragmentary

${ }^{12}$ HunTER and DiCKENS 2014, 466. Evidence of the quire composition can be seen in the fragments SyrHT 71 and SyrHT 72 where the stiching thread are intact and in SyrHT 78, SyrHT 80, SyrHT 94, SyrHT 95 where the stiching holes are easily recognizable. See in particular: DiCKENS 2013, 11-12.

${ }^{13}$ For editorial reasons we will not include photo reproductions of all cited fragments. Anyway the Christian Sogdian and Syriac fragments are digitalized and available online: http://turfan.bbaw.de/dta/n/dta_n_index.html and http://idp.bl.uk/database/ respectively.

${ }^{14}$ The codex is the book format with particular regard to the material under investigation. On a questionable example of a pothī fragment, see SIMS-WILLIAMS 2012, 62.

${ }^{15}$ Therefore we will leave aside those cases that do not allow us to make any considerations other than that they may show traces of a quire-number. These traces have been already discussed in Sims-WiLliams 2012 as well as in HunTER and Dickens 2014. We are referring to the fragments E28/80 (Sims-Williams 2012, 155); E28/90 (Sims-Williams 2012, 157); E28/122 (Sims-Williams 2012, 162); SyrHT 76 (HunTER and Dickens 2014, 91); SyrHT 81\&82 (Hunter and Dickens 2014, 98); SyrHT 85a (HunTer and Dickens 2014, 102); SyrHT 123 (HunTER and Dickens 2014, 137); SyrHT 125 (HunTER and Dickens 2014, 140); SyrHT 145 (Hunter and Dickens 2014, 156); SyrHT 191a (HunTER and Dickens 2014, 194195); SyrHT 231 (HunTER and Dickens 2014, 229); SyrHT 307 (HunTER and Dickens 2014, 286); SyrHT 325 (Hunter and Dickens 2014, 300); SyrHT 327 (HunTER and Dickens 2014, 301); SyrHT 348 (Hunter and Dickens 2014, 314); and n416 (HunTER and Dickens 2014, 408). 
manuscript traditions ${ }^{16}$ — we can provide new tools for the understanding of the material which has been preserved.

\subsection{Manuscript fragments E5, E27, SyrHT 72 and the Christian Palestinian Aramaic ${ }^{17}$ Manuscripts: the "mirror" 18 signature}

The group of manuscript fragments known as $\mathrm{E} 5^{19}(19.5-20 \times 14.5-15 \mathrm{~cm})^{20}$ comes from a gospel lectionary in Sogdian language in East Syriac script with rubrics and the opening words of each new Gospel passage in the Syriac language in East Syriac script (followed by a Sogdian translation). The quirenumbers attested in the manuscript fragments E5 are placed in the middle of the bottom margin, even if in one case, E5/51/r/, this position can only be inferred because a small portion of the fragment is preserved. The quirenumbers are always enclosed by two ornamental rhombs of four dots. The quire-numbers are in black ink like the main text. The rhombs show the use of black ink and red ink. The two horizontally opposed dots are in black ink and those vertically opposed are in red ink. The quire-numbers we find are:

$\mathrm{E} 5 / 41^{21} / \mathrm{r} /: \mathrm{d}=4$, i.e. the first page of the fourth quire (PI. 1)

$\mathrm{E} 5 / 51^{22} / \mathrm{r} / \mathrm{h} \mathrm{h}=5$, i.e. the first page of the fifth quire (PI. 2)

$\mathrm{E} 5 / 91^{23} / \mathrm{r} /: \mathrm{t}=9$, i.e. the first page of the ninth quire (PI. 3)

$\mathrm{E} 5 / 100^{24} / \mathrm{v} /: \mathrm{y}=10$, i.e. the last page of the ninth quire $(\mathbf{P I} \mathbf{. 4})$

$\mathrm{E} 5 / 101^{25} / \mathrm{r} /: \mathrm{y}=10$, i.e. the first page of the tenth quire (PI. 5)

${ }^{16}$ In particular, I am referring to the studies carried out on the Coptic manuscript fragments as well as on the Dead Sea scrolls. See BARBATI 2015 [2014].

${ }^{17}$ Christian Palestinian Aramaic is the Aramaic dialect spoken and written beside Greek in Palestine and Arabia in the Melkite communities not using regularly Greek during the Byzantine, the Umayyad and Abbasid periods. I am extremely grateful to Alain Desreumaux for suggesting this definition. Personal communication 18.05.2018.

${ }^{18}$ Desreumaux 2015, 134.

${ }^{19}$ BARBATI 2016.

${ }^{20}$ BARBATI 2016, 29.

${ }^{21} \mathrm{E} 5 / 41=\mathrm{n} 500 *$. E5/41 recalls the new classification system introduced by Sims-Williams in his catalogue. See Sims-Williams 2012, 11-16. n500* is the signature one can find at the Digital Turfan Archive, http://turfan.bbw.de/dta/n/dta_n_index.html. The same applies for all other cases. Finally, in n500*, the asterisk indicates that the fragment is lost and that we only have a photo reproduction preserved at the Niedersächsische Staats- und Universitätsbibliothek Göttingen, bequest of Carl Friedrich Andreas.

\footnotetext{
${ }^{22} \mathrm{E} 5 / 51=\mathrm{n} 154$.

${ }^{23} \mathrm{E} 5 / 91=\mathrm{n} 162$.

${ }^{24} \mathrm{E} 5 / 100=\mathrm{n} 160$.

${ }^{25} \mathrm{E} 5 / 101=\mathrm{n} 161$.
} 


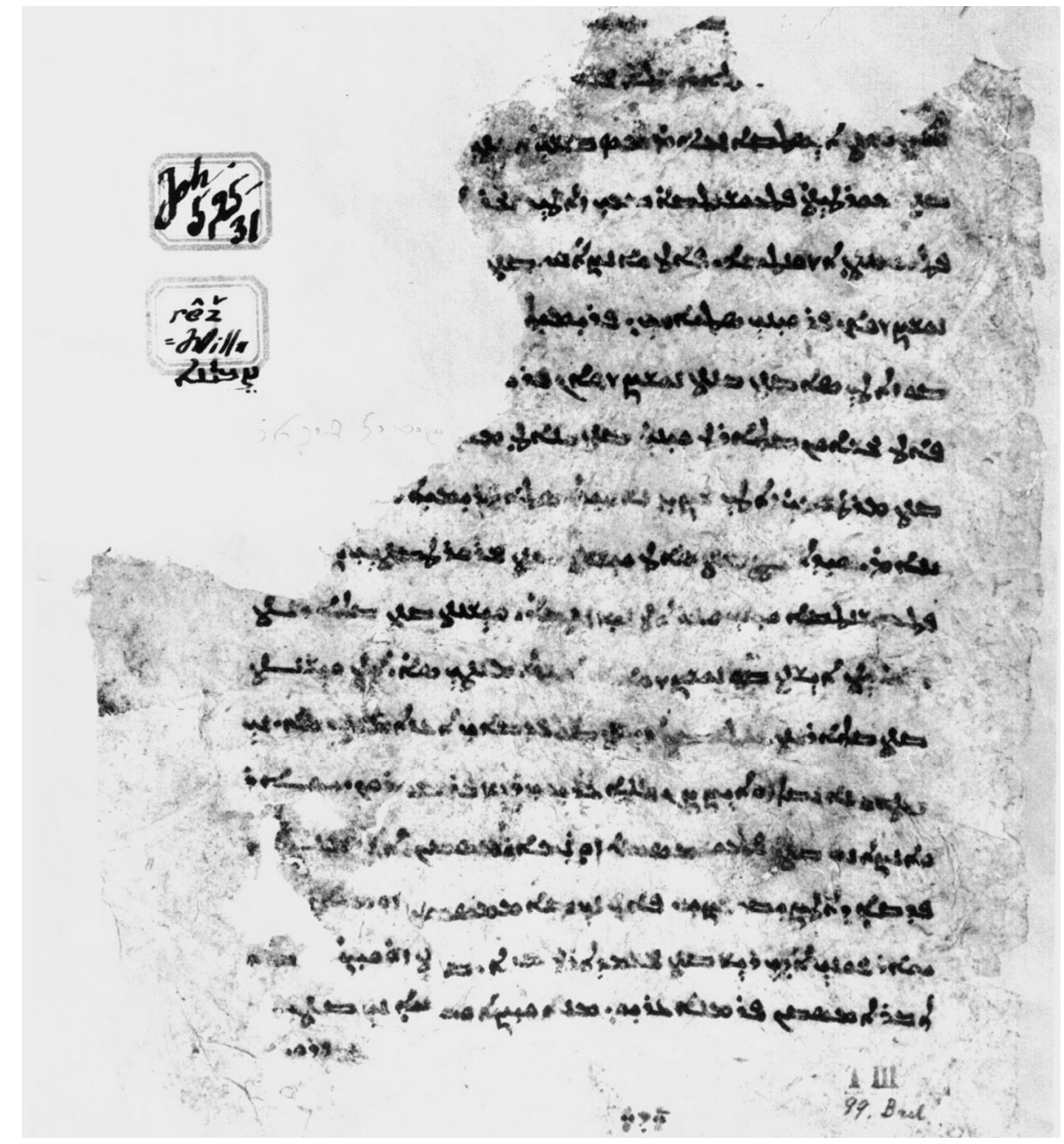

Pl. 1.

$\mathrm{E} 5 / 41 / \mathrm{r} /=\mathrm{n} 500 *$ recto 
98

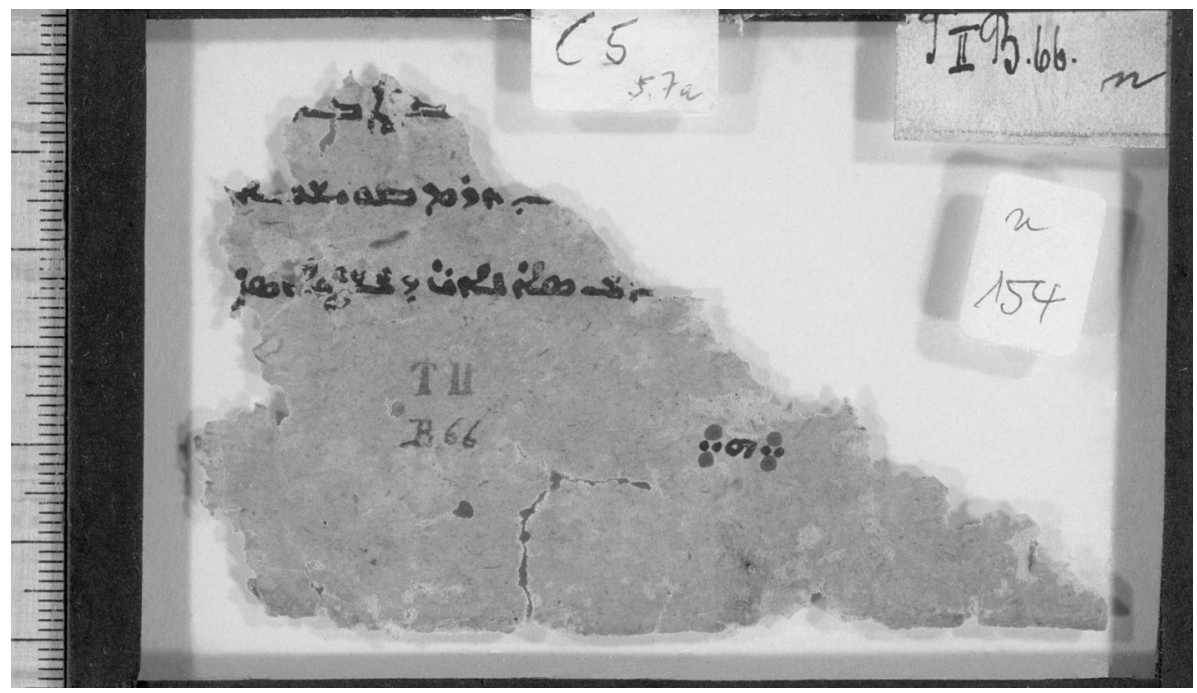

$$
\text { Pl. } 2 .
$$

$\mathrm{E} 5 / 51 / \mathrm{r} /=\mathrm{n} 154$ recto 


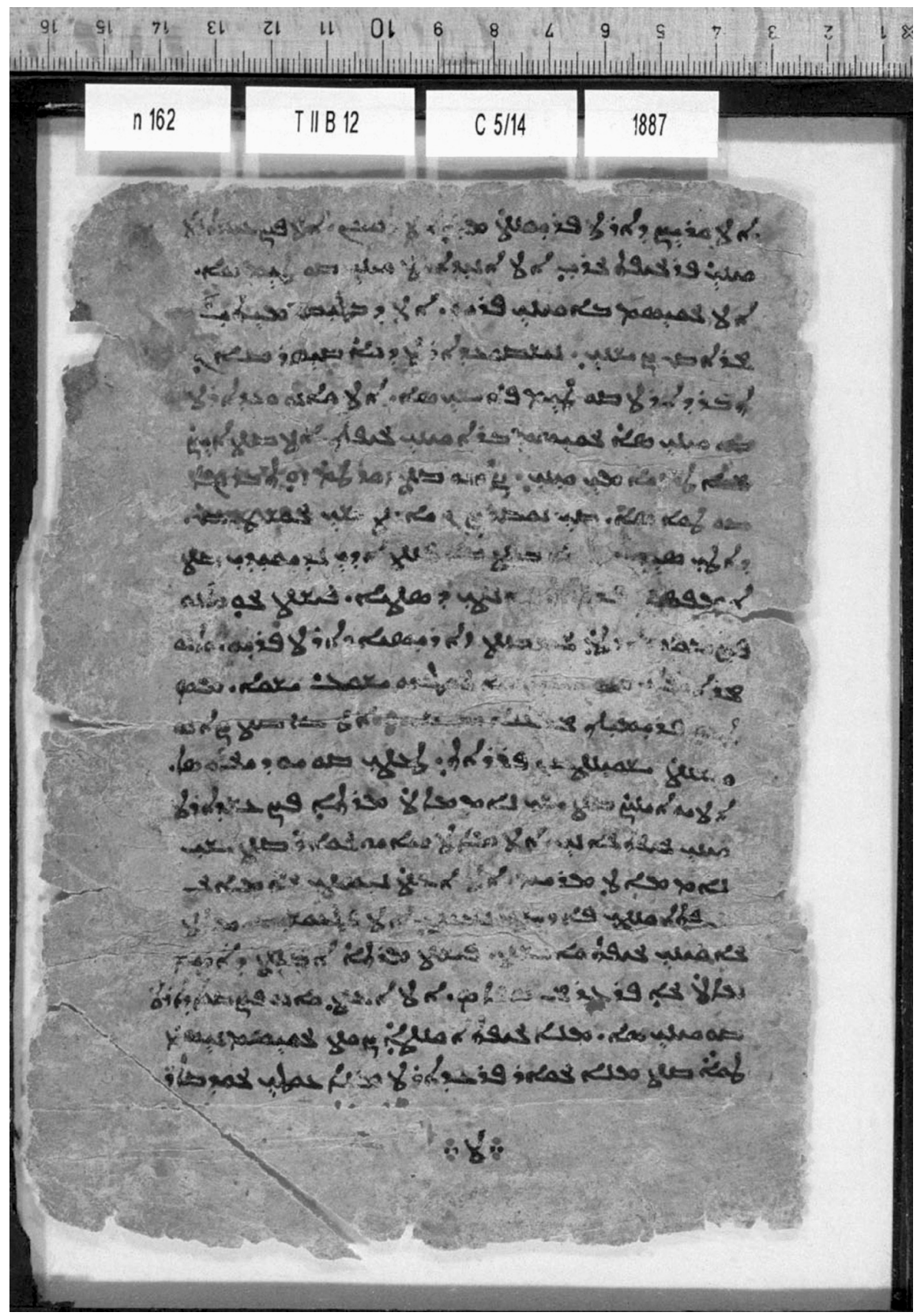

Pl. 3.

$\mathrm{E} 5 / 91 / \mathrm{r} /=\mathrm{n} 162$ recto 


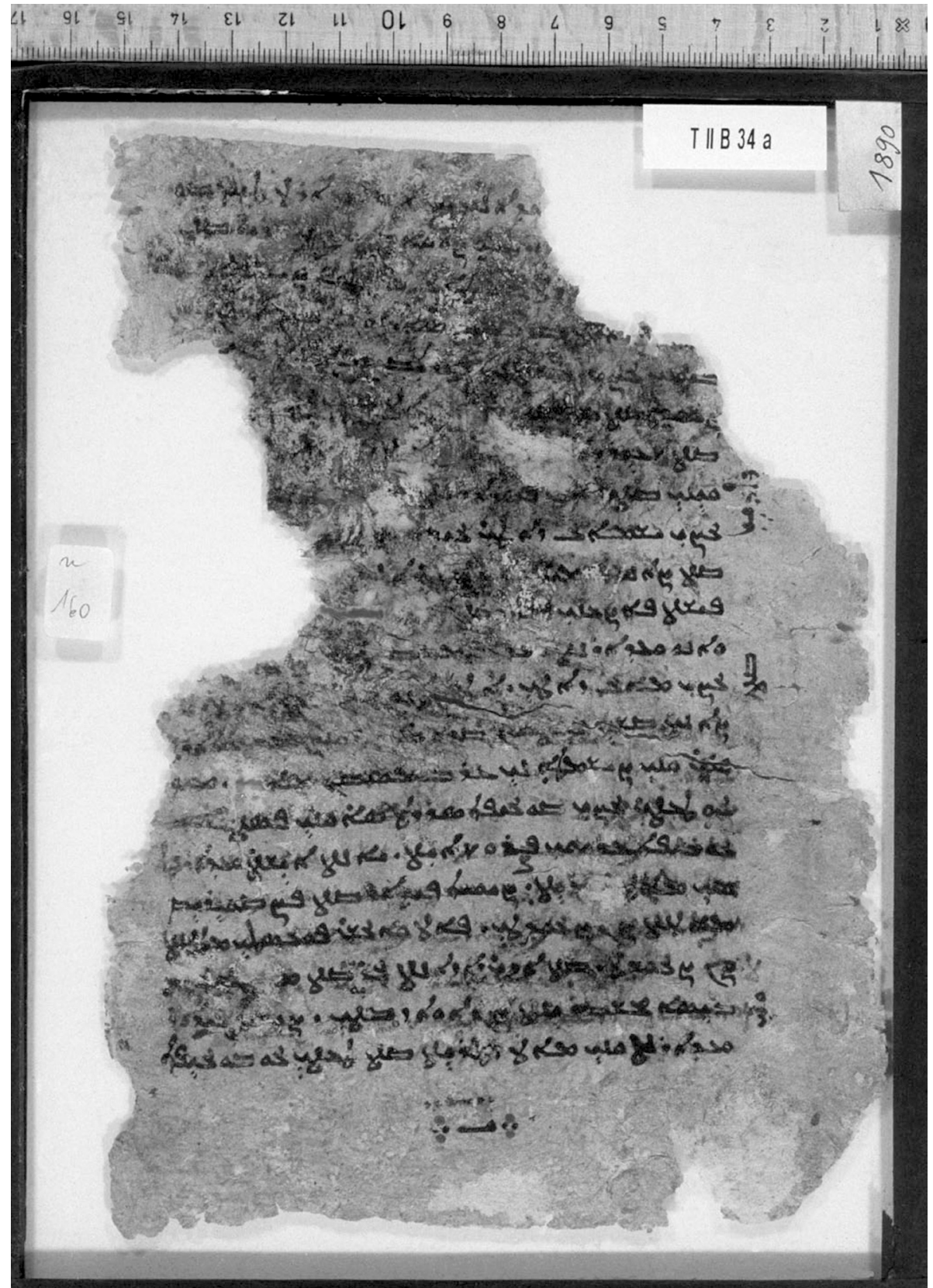

Pl. 4.

$\mathrm{E} 5 / 100 / \mathrm{v} /=\mathrm{n} 160$ verso 


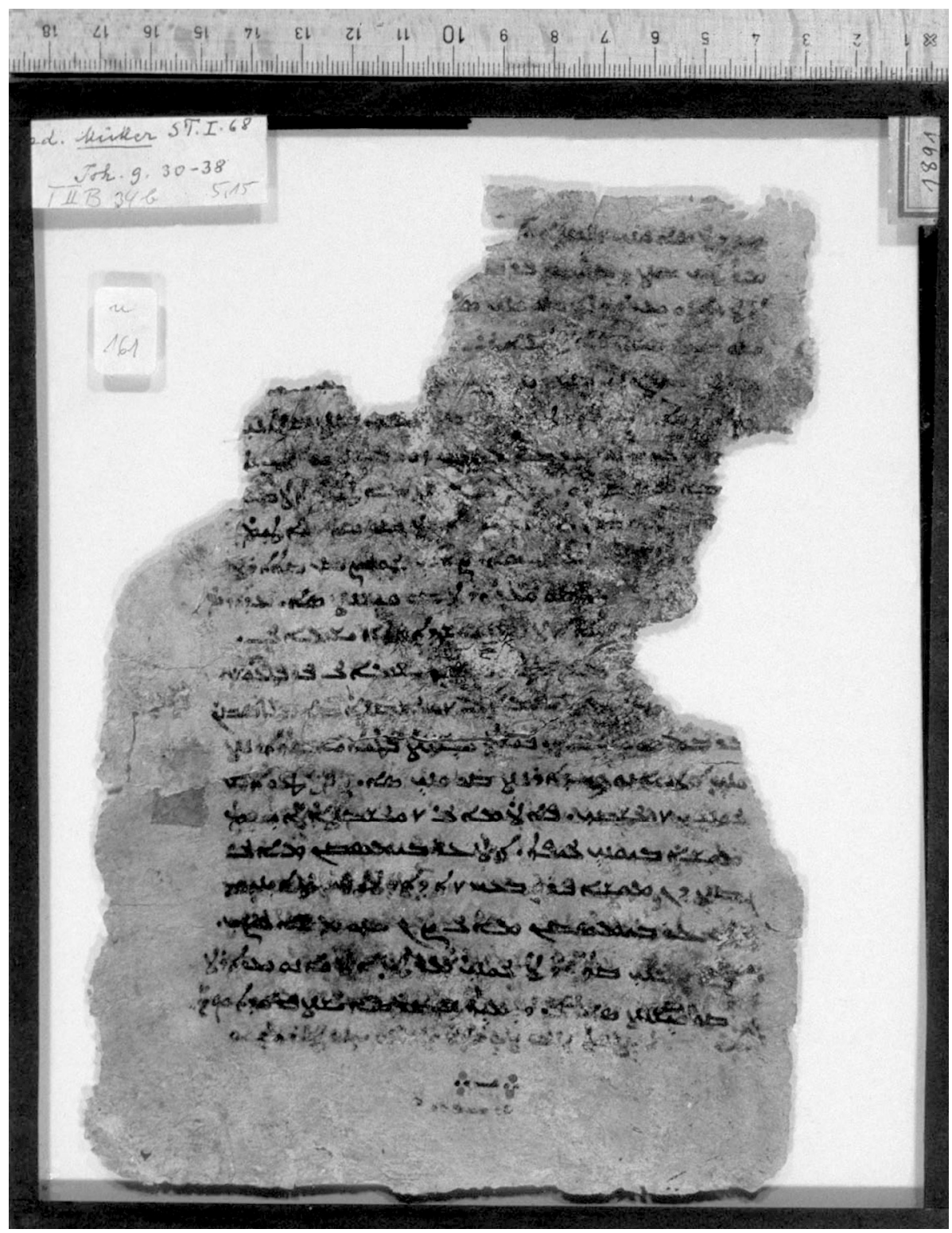

Pl. 5.

$\mathrm{E} 5 / 101 / \mathrm{r} /=\mathrm{n} 161$ recto 
Already Sundermann ${ }^{26}$ and Sims-Williams ${ }^{27}$ have emphasized that the last page of the ninth quire and the first page of the tenth quire of this manuscript bear the same number and that this system differs from the standard Syriac quire-numbering system, citing as an example the Syriac manuscript fragment SyrHT 72. The aim of the present contribution is to go further and propose a new working hypothesis.

Following Sims-Williams, the Christian Sogdian manuscript fragments known as E27 attest the same peculiarity. In the fragment E27/60/v/ and in the fragment E27/61/r/ Sims-Williams reads the quire number $\mathrm{w}=6$ (on my possible alternative reading see below).

The group of manuscript fragments E27 $(31-32 \times 19.5-20 \mathrm{~cm})^{28}$ is an example of a monastic miscellany or monastic multiple-text manuscript. ${ }^{29}$ It represents several text genres: Sims-Williams counts at least thirteen distinct texts covering a range from metrical homilies to general Christian literature. All texts are written in the Sogdian language in East Syriac script. The occurences of the quire-numbers are:

$\mathrm{E} 27 / 31^{30} / \mathrm{r} / \mathrm{g} \mathrm{g}=3$, i.e. the first page of the third quire (PI. 6)

The quire-number is not exactly placed in the middle of the bottom margin but towards the inner margin. It is enclosed by decorative pointing: two internal horizontal points with four points, one above, one below, one to the right and one to the left of the two internal horizontal points. It seems to me that they form a cross. Two crosses enclose the quire number and the other are extended across the bottom margin. Because of the loss of the original fragment, we only have a photo reproduction. Therefore, it is particularly difficult to be more precise on the exact number of the points as well as on the colour of the ink. Nevertheless, I would cautiously suggest that the two internal horizontal points are in black ink and the other four in a different colour - maybe in red - because this is the colour we find for the same decorative points in other fragments belonging to the manuscript E27.

\footnotetext{
${ }^{26}$ SUNDERMANN 1975, 87-90.

${ }^{27}$ SiMS-WILLIAMS 1985, 14-15.

${ }^{28}$ Sims-Williams 1985; Sims-WiLliams 2012, 99-126.

${ }^{29}$ On the use of the terms manuscript miscellany or multiple-text manuscript, see FRIEDRICH and SCHWARKE 2016. On the difficult one may have in defining and distinguishing a multiple text manuscript from a composite manuscript when we are dealing with manuscript traditions in a fragmentary status, one can recalls the recent study of Buzi focused on the Coptic manuscript tradition. See Buzi 2016. With particular regard to the Syriac monastic miscellanies (or multiple-text manuscripts), see KESSEL 2014.

${ }^{30} \mathrm{E} 27 / 31=\mathrm{n} 520^{*}$, unidentified homily on the three periods of the solitary life.
} 


\section{$\mathrm{E} 27 / 51 \mathrm{c}^{31} / \mathrm{r} /: \mathrm{h}=5$, i.e. the first page of the fifth quire (PI. 7)}

Only a portion of the bottom margin has been preserved. Therefore we are not able to establish the precise position. Taking into account that the measures of E27 are $31-32 \times 19.5-20.5 \mathrm{~cm}^{32}$ and that the measures of the fragments are $12 \times 10.5 \mathrm{~cm},{ }^{33}$ one can infer that the quire should be approximately in the middle of the bottom page as in the other and better preserved occurrences of the manuscript fragments E27. With particular regard to the decorative pointing, we have the same features discussed for the previous fragment: the difference is that in this case the alternation between the black ink in the two internal horizontal points and the red ink of the four point, one above, one below, one to the right and one to the left is visible. The two crosses that enclose the quire number are also visible, then only one to the outer margin is preserved.

$\mathrm{E} 27 / 60^{34} / \mathrm{v} /: \mathrm{w}=6$, i.e. the last page of the fifth quire (PI. 8)

The quire number is placed in the middle of the bottom margin and it shows the same decorative pointing that has been discussed in the previous two examples. In this case, the page is well preserved and one can clearly observe the position of the quire-number which is in the middle of the bottom margin and enclosed by two crosses formed by the decorative pointing already discussed, the decorative points across the margin by starting and finishing next to the written area, and, finally, the alternation of black and red ink.

$\mathrm{E} 27 / 61^{35} / \mathrm{r} /: \mathrm{w}=6$, i.e. the first page of the sixth quire? (PI. 9)

Because of the fragmentary preservation of the portion of the manuscript involved, I am not sure one is able to give a certain reading. The reading of $\mathrm{w}$ is possible but, if so, I would expect a roundish ductus with particular regard to the upper part of the letter like in the previous fragment E27/51 c/r/. I would suggest $t$ but if we look at the occurrences of this letter within the text one can observe that the ductus is inclined to the right and not to the left like seems to me in the quire-number. Therefore I would prefer to leave it as an open question and not taking the manuscript E27 as a sure example of the same number used for the last page of a quire and for the first page of the next quire as in E5. With particular regard the quire ornaments, we find the same system of all previous fragments.

E27/127\% $/ \mathrm{v} /$ : former presence of a quire number $(\mathbf{P I . ~ 1 0})$

\footnotetext{
${ }^{31} \mathrm{E} 27 / 51 \mathrm{c}=\mathrm{n} 494$, part of the homily of Bābay of Nisibis.

${ }^{32}$ Sims-Williams 2012, 99.

${ }^{33}$ Sims-WiLliams 2012, 110.

${ }^{34} \mathrm{E} 27 / 60=\mathrm{n} 489$, excerpts from the Apoththegmata Patrum.

${ }^{35} \mathrm{E} 27 / 61=\mathrm{n} 493$, questions and answers from the Apoththegmata Patrum.

${ }^{36} \mathrm{E} 27 / 127=\mathrm{n} 36$, probably part of the Apoththegmata Patrum.
} 
According to Sims-Williams, the decorative pointing on the bottom margin indicates the former presence of a quire-number. ${ }^{37}$ The kind of decorative pointing seems to be the same of the decorative pointing of the previous fragments even if it is not clear, at least to me, whether the point in black is two or one points and if there was an upper point in red ink.

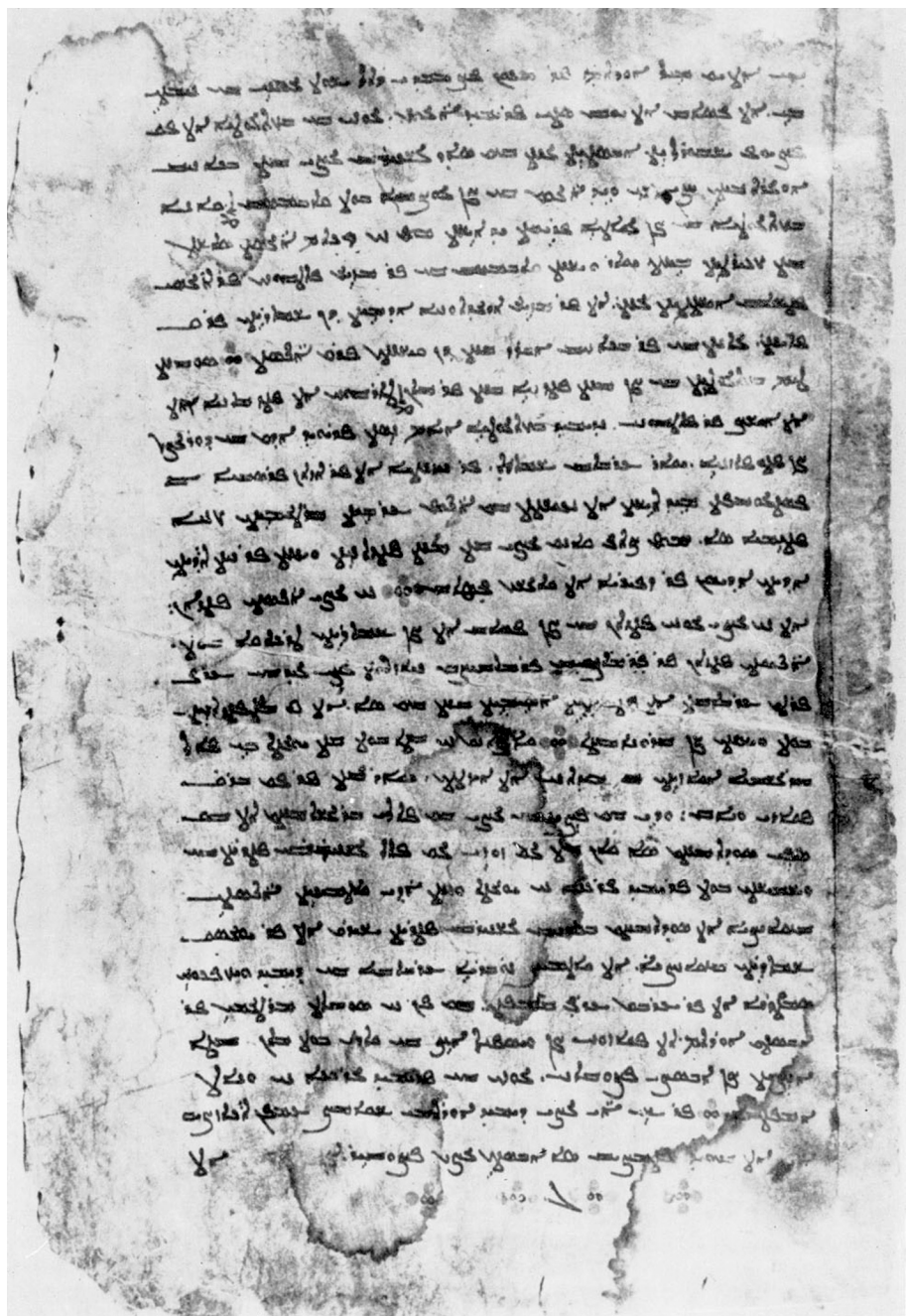

Pl. 6.

$\mathrm{E} 27 / 31 / \mathrm{r} /=\mathrm{n} 520 *$ recto

${ }^{37}$ Sims-Williams 2012, 123. 


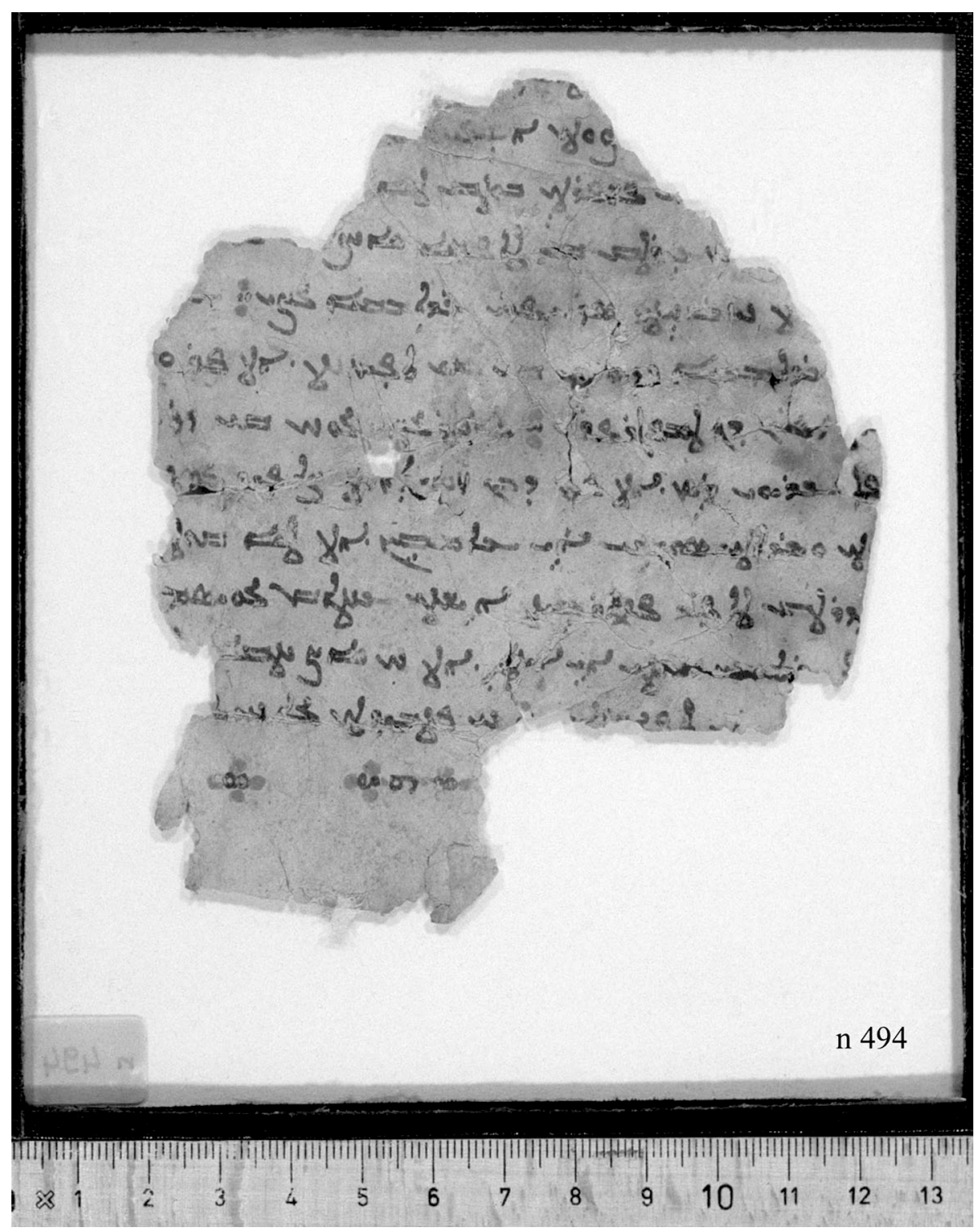

Pl. 7.

$\mathrm{E} 27 / 51 \mathrm{c} / \mathrm{r} /=\mathrm{n} 494$ recto 


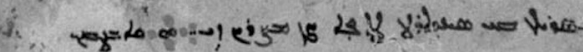

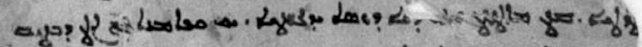

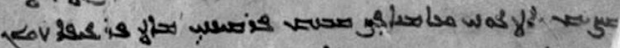

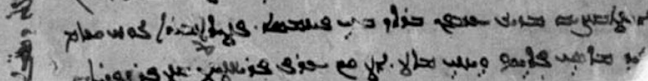

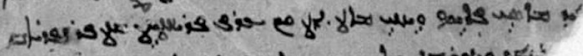

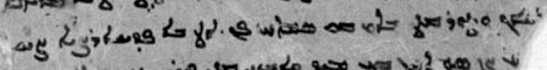

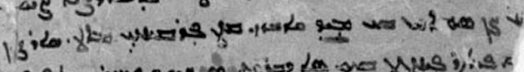

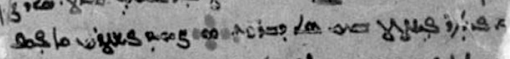

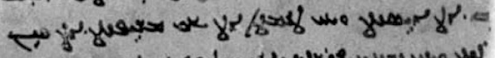

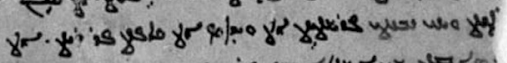
5. क.

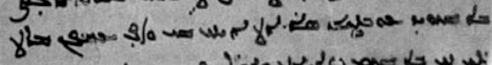

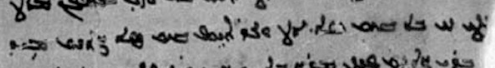

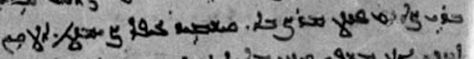

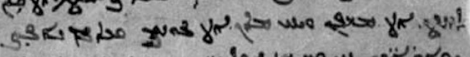

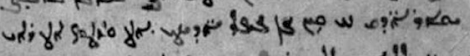

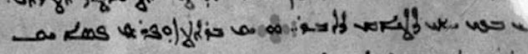

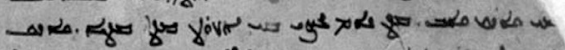

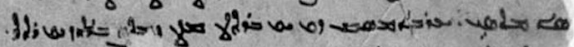

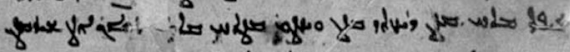

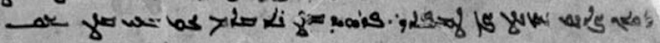

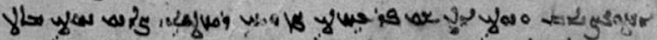

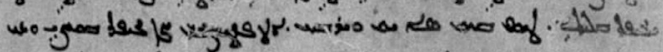

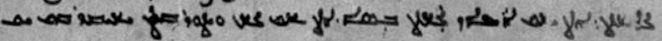

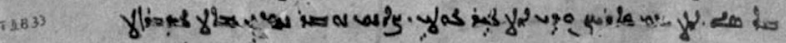

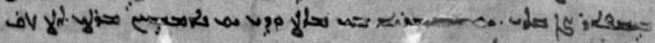

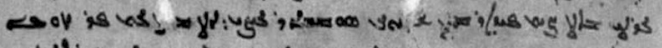

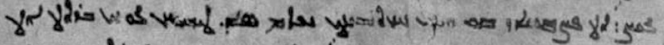

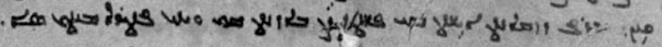

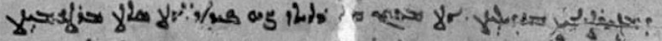

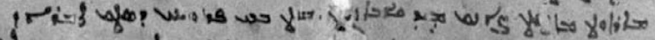

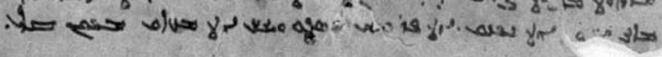

Pl. 8.

$\mathrm{E} 27 / 60 / \mathrm{v} /=\mathrm{n} 489$ verso 


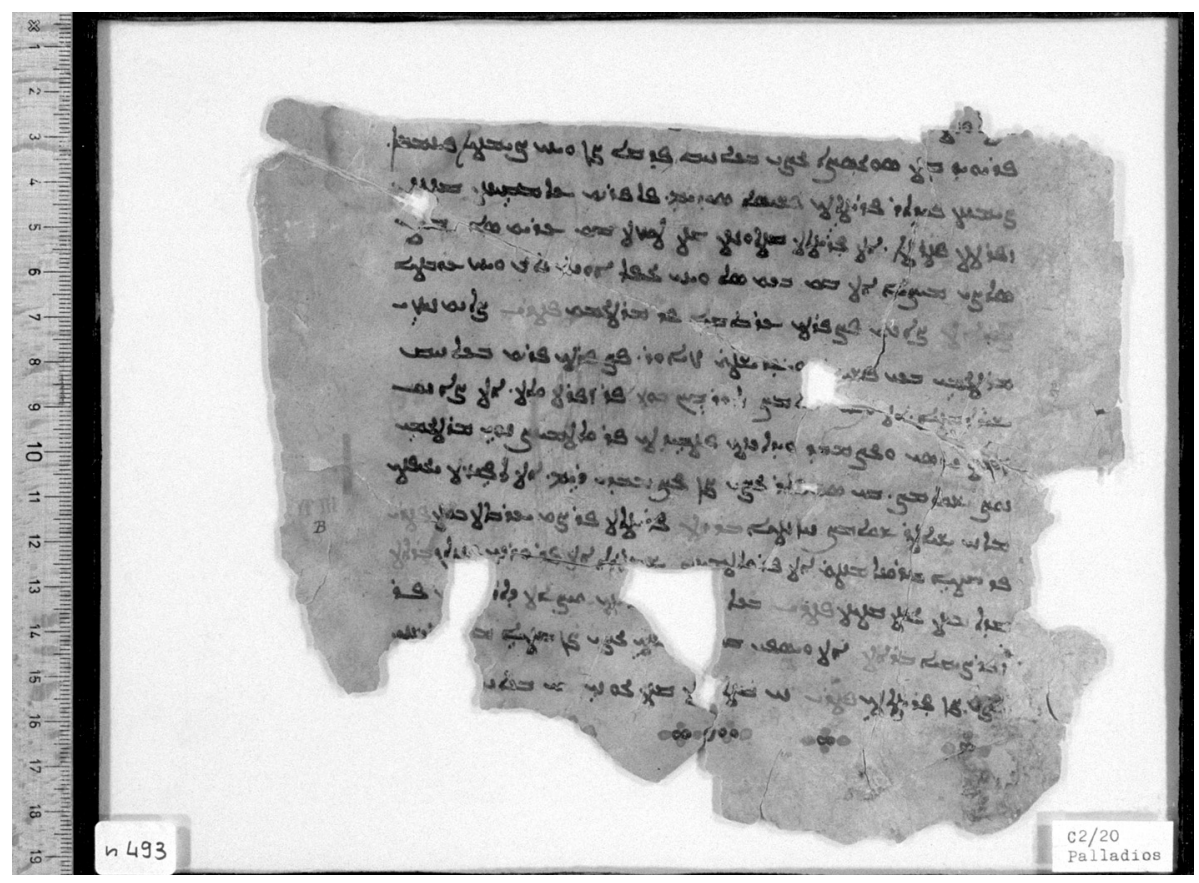

P1. 9.

E27/61/r/= n 493 recto

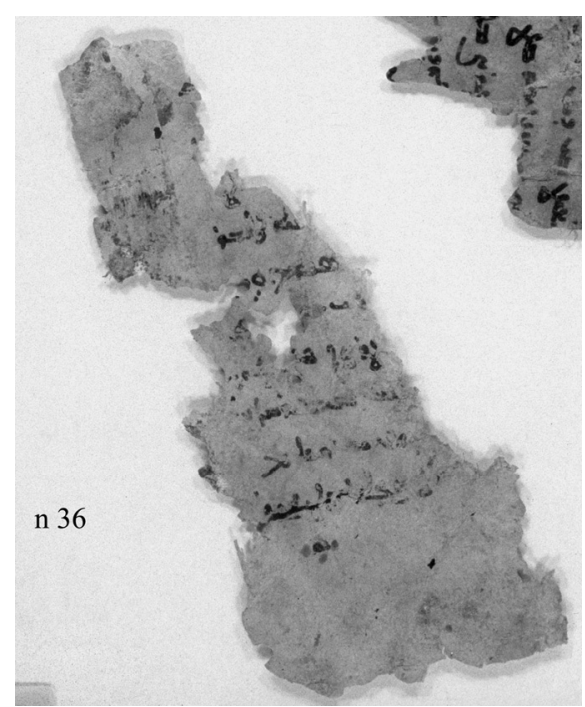

Pl. 10.

$\mathrm{E} 27 / 127 / \mathrm{v} /=$ n 36 verso 
To sum up, I am more inclined to consider the "mirror" signature system as a peculiarity of the manuscript fragments E5. If this is so, it would be the only case attested in the Christian Sogdian manuscript fragments in the Berlin Turfan Collection. Of course, we have to keep in mind that we are dealing with fragments. Therefore, we always have to confront the possibility that the absence of a specific phenomenon among the fragments does not necessarily mean that it is an absence from the manuscript tradition.

If we look at the Syriac manuscript tradition in general, we find that both the position of the quire number in the middle of the bottom margin and the numbering of the last and first page of a quire with the same number is a standard practice. Numbering the last page of a quire and the first page of the following quire with the same number is a very uncommon feature. Nevertheless, it is a peculiarity we find within another manuscript tradition within eastern Christianity, namely the Christian Palestinian Aramaic manuscript tradition.

Desreumaux wrote on the manuscripts in Cambridge: ${ }^{38}$ " ...the quires are mirror-signed, a system that seems to be characteristic of Christian Palestinian manuscripts (in any case, this system is not found in Syriac manuscript): the verso of the last leaf of quire 1 and the recto of the first leaf of quire 2 are signed with alaph=1; the verso of the last leaf of quire 2 and the recto of the first leaf of quire 3 are signed beth $=2$, and so on in such manner that the position of a quire within the codex is known from the verso of the last leaf of the quire, the mirror-signature being there to ensure the correct succession of the quires. Moreover, in certain manuscripts such as the Cambridge lectionary of Westminster College (Lewis 1897), the letters do not really correspond to Semitic numbering system; indeed, after initial kaf form comes the final kaf form,... The remains of manuscript Sinai, New Finds M58-59N display and identical system". Speaking of the manuscripts of the medieval period, ${ }^{39}$ Desreumaux asserts that they are composed of quaternion and are mirror-signed. It seems that he is referring to the parchment manuscripts. In any case, concerning the paper manuscripts he asserted (COMSt 2012: 135): "it is difficult to draw a general rule, for there is only a very small number of them, and only two are complete books, nevertheless with particular regard

\footnotetext{
${ }^{38}$ DesReumaux 2015, 134.

${ }^{39}$ Medieval period means tenth to twelfth centuries, ancient period means fifth to tenth centuries. See DesReumaux 2015, 132.
} 
to the numbering of the quires, it is important to stress that they are both "mirror-signed". ${ }^{40}$

The presence of the Melkite Church in Central Asia and in Turfan is well attested. ${ }^{41}$ With particular regard to the manuscript fragments E5, it is worth mentioning that the literary and the material aspects point in the same direction. From a literary perspective, the Christian texts found ${ }^{42}$ in Turfan mostly belong to the Church of the East, except for the lectionary E5 which cannot be counted as a standard lectionary of the Church of the East and appears to be closer to the Melkite Church (even with peculiarities), as I have discussed in my recent book. ${ }^{43}$

At this point, I add another piece of evidence taking into account material aspects, i.e. quire-numbering. As already asserted in the previous pages, the fact that quire numbering as attested in E5 differs from the standard Syriac practice has been known since the 1970s, but it had not been observed that this peculiarity is shared with the Christian Palestinian Aramaic manuscript tradition. At this early stage ${ }^{44}$ is extremely difficult to understand and to explain what this fact really means; on the other hand, it must be taken into account if we want to go further in our analysis. This approach also testifies to the importance of combining the study of literary aspects together with the study of material aspects in order to obtain the whole picture of a problem. In turn, it is also the main reason for publishing a volume focused on the

${ }^{40}$ Desreumaux 2015, 135. I would like to thank Alain Desreumaux and Sebastian Brock for the interesting discussion we have on the occasion of the Conference "New light on old manuscripts. Recent advances in palimpsest studies", Vienna, 26 April 2018. Since the "mirror" signature system is quite unusual for the Syriac manuscripts, it is worth to continue to explore the link between the Christian manuscript tradition as attested in Turfan and the Christian Palestinian manuscript traditions.

${ }^{41}$ One can briefly recall: 1) Barshabbā, legendary bishop of Marv, founder of the Christian Church in eastern Iran. The complete legend is preserved only in Arabic sources but we have some evidences in few Sogdian fragments coming from Xinjiang too (fragments E24/7-11: Sims-Williams 2012, 75-77); 2) a unique fragment contains part of Psalm 33 (according to the numbering of Septuaginta) with Greek quotations as headlines and which agrees with the Septuaginta, Sims-WiLliams 2004.

${ }^{42}$ Which does not necessarily means that the whole material under investigation has been produced in Turfan. BARBATI 2015a, 92-97.

${ }^{43}$ BARBATI 2016, 41-57. See also the review of Pirtea with particular regard to the commemoration of Barshabbā, Sergius and Bacchus as attested in E5: PIRTEA 2018, 113-115.

${ }^{44}$ One has to keep in mind that that study of the Christian manuscript tradition as attested in the Syriac and Christian Sogdian manuscript fragments found in Turfan is far away from being deeply studied and understood. See BARBATI 2017. 
Iranian manuscript traditions other than Islamic, as a way of trying to encourage and develop this approach as field of research within Middle Iranian Studies.

Concerning the Syriac manuscript fragments in the Turfan Collection, Sundermann $^{45}$ and Sims-Williams ${ }^{46}$ both noted the "mirror" quire-numbering in the manuscript fragments SyrHT 72. SyrHt $72(15.9 \times 11.9 \mathrm{~cm})^{47}$ consists of nine pages stitched together and of four separate fragments, i.e. SyrHT 348 , SyrHT 228, SyrHT 379, SyrHT $79 .{ }^{48}$ The attested quire-numbers are to be found in the pages stitched together and the occurences are the following:

SyrHT $722 \mathrm{a}^{49}: \mathrm{h}=8$, i.e. the first page of the eighth quire (PI. 12)

The quire-number is in the bottom margin and it is repeated twice, in the lower right and lower left corners, with decorative punctuation points.

SyrHT 72 3a: $\mathrm{nn}=50$, i.e. the first page of the fiftieth quire (Pl. 13)

The quire-number is in the bottom margin and it is repeated twice, in the lower right and lower left corners, with decorative punctuation points.

SyrHT $724 b^{50}: p=80$. i.e. the last page of the eightieth quire (PI. 14)

The quire-number is in the bottom margin and it is repeated twice, in the lower right and lower left corners, with decorative punctuation points.

SyrHT 72 5a: $p=80$, i.e. the first page of the eightieth quire (PI. 15)

The quire-number is in the bottom margin and it is repeated twice, in the lower right and lower left corners, with decorative punctuation points.

The last two occurrences testify to the "mirror" signature system, i.e. the use of the same number for the last page of a quire as well as for the first page of the following quire.

To the extent they are still visible, the decorative punctuation points that enclose the quire-number in SyrHT 72 1a and in SyrHT 72 2a the five points - two before the quire-number and tree after the quire-number - in

\footnotetext{
${ }^{45}$ SUNDERMANN 1975, 87-90.

${ }^{46}$ Sims-WiLliams 1985, 14-15.

${ }^{47}$ HUNTER and DiCKENS 2014, 85.

${ }^{48}$ DiCKENS 2013a, 366.

${ }^{49}$ Meaning recto. With particular regard to the Syriac fragments, I follow the signatures of the catalogue (HUNTER and DiCKENS 2014) which also correspond to the signature which are available online throught the International Dunhuang Project. The occurences discussed above are listed in the catalogue of HunTER and DiCKENS 2014, 85 with the exception of SyrHT 72 1a (Pl. 11) where it is quite impossible to read the quire-number.

${ }^{50}$ Meaning verso. See the previous note.
} 
the right lower corner are in black ink, whereas in the lower left corner two vertical point are in red ink and two horizontal point in black ink. In SyrHT 72 3a, in SyrHT 72 4b and in SyrHT 72 5a in both corner, the two horizontal point are in black, the two vertical points in red. ${ }^{51}$ In SyrHT 72 4a we have two vertical points in red ink twice on the lower left margin, once on the lower right margin. In SyrHT72 5b two vertical point in red in the lower margin, two on the right side, two on the left side.

From a literary point of view, SyrHT 72 contains the psalter consisting of Peshitta psalms, psalm numbers, rubricated psalm heading and rubricated canons. ${ }^{52}$ The text is written in the Syriac language in East Syriac script. It is worth recalling what Dickens clearly pointed out: "The Turfan Psalter finds are important for two reasons. First, no other Christian text found at Turfan was rendered in more languages and scripts than the Psalter and second, the Syriac Psalter fragments from Turfan are amongst the earliest of the Syriac Peshitta text of the Psalms". 53

Moreover, from the point of view of material aspects, SyrHT72 shows another peculiarity that is rare among the Syriac and Christian Sogdian manuscript fragments from Turfan, namely, ruled margins, ${ }^{54}$ which is in this case are very visible in SyrHT 72 1a (Pl. 11). Once again, we are dealing with a fragment that differs in many respects from Syriac standard practices as reflected in the Syriac and Christian Sogdian fragments from the Berlin Turfan Collection.

The repetition of the quire-number as attested in SyrHT 72 is also recognizable in the Christian Sogdian manuscript fragment E26 and, generally speaking, is listed as an exception within the Syriac manuscripts. ${ }^{55}$

${ }^{51}$ According to HuNTER and DiCKENS 2014, 85 red ink is visible in SyrHT 72 4a and SyrHT 725 b as "ink transfer from quire marks on adjacent (lost) folios".

${ }^{52}$ HunTER and DiCKENS 2014, 84-87.

${ }^{53}$ Dickens 2013, 358. On a deeply analysis of the attested psalms, see DicKENS 2013, 366-367; HUNTER and DiCKENS 2014, 84-85.

${ }^{54}$ Dickens 2013, 366. The Christian Sogdian fragments shows few cases of the ruled margin. On an overview and a first work hypothesis on the ruled margin in the Christian Sogdian manuscript fragments from Turfan, see BARBATI 2017, 406-407.

${ }_{55}$ As we have seen in the first paragraph of this contribution, BORBONE and BRIQUELChatonnet quoted as exception the manuscript London, BL, Add. 14548 (790), f. 33r. BORBONE and BRIQUEL-ChATONNET and BALICKA-WITAKOWSKA 2015, 256. 


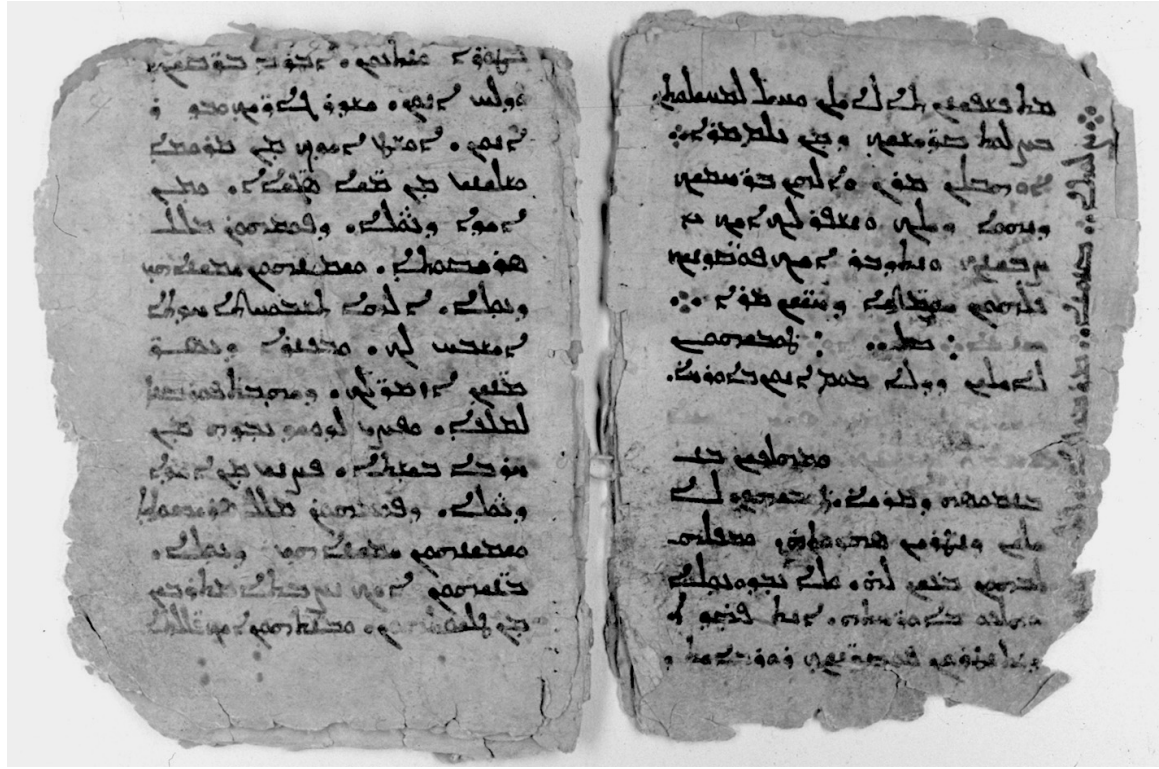

Pl. 11.

SyrHT 72 1a recto

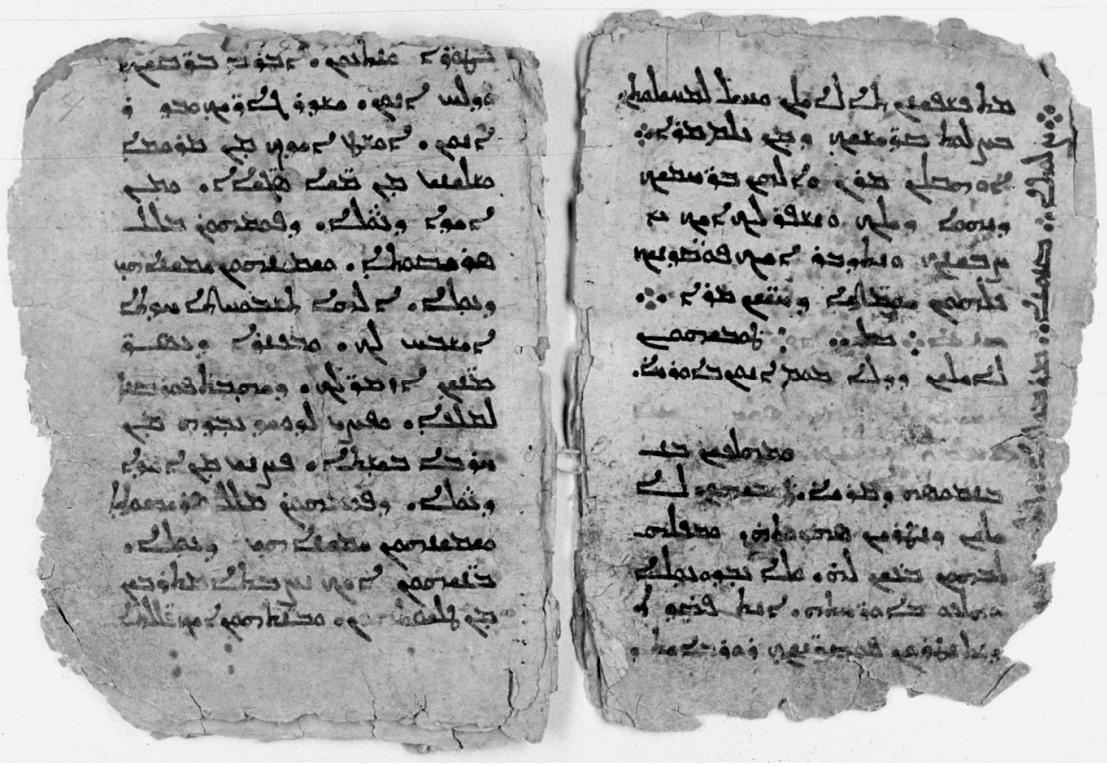

P1. 12.

SyrHT 72 2a recto 


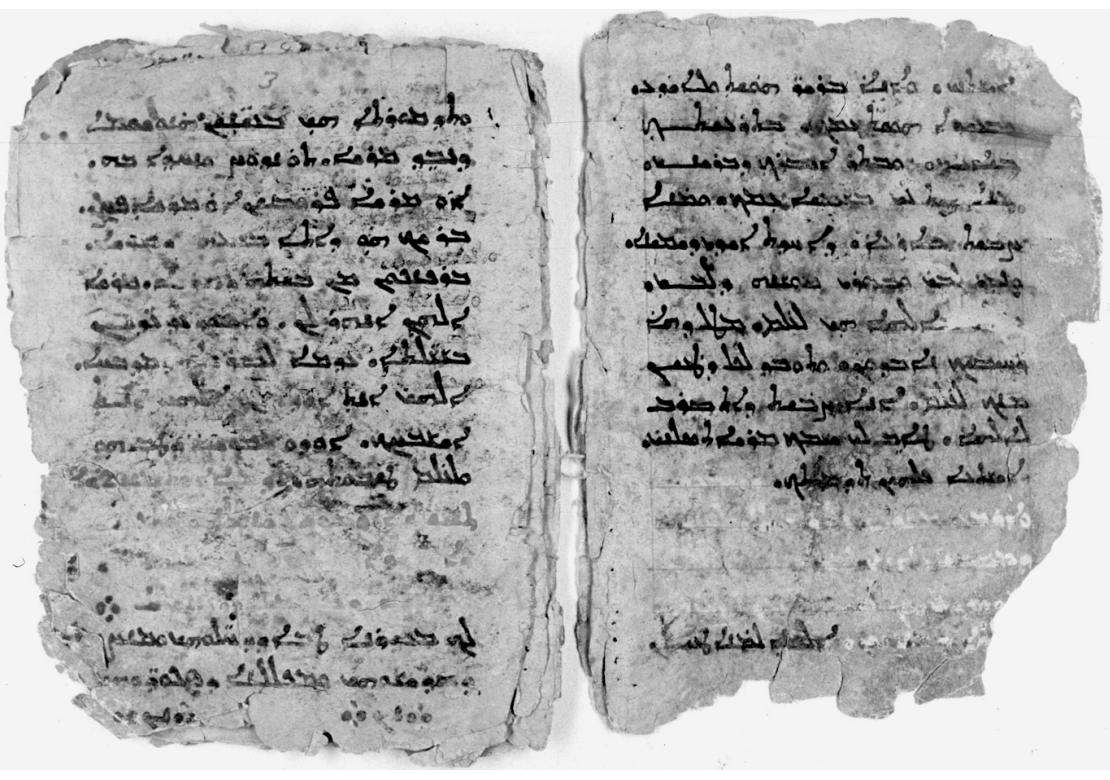

P1. 13.

SyrHT 72 3a recto

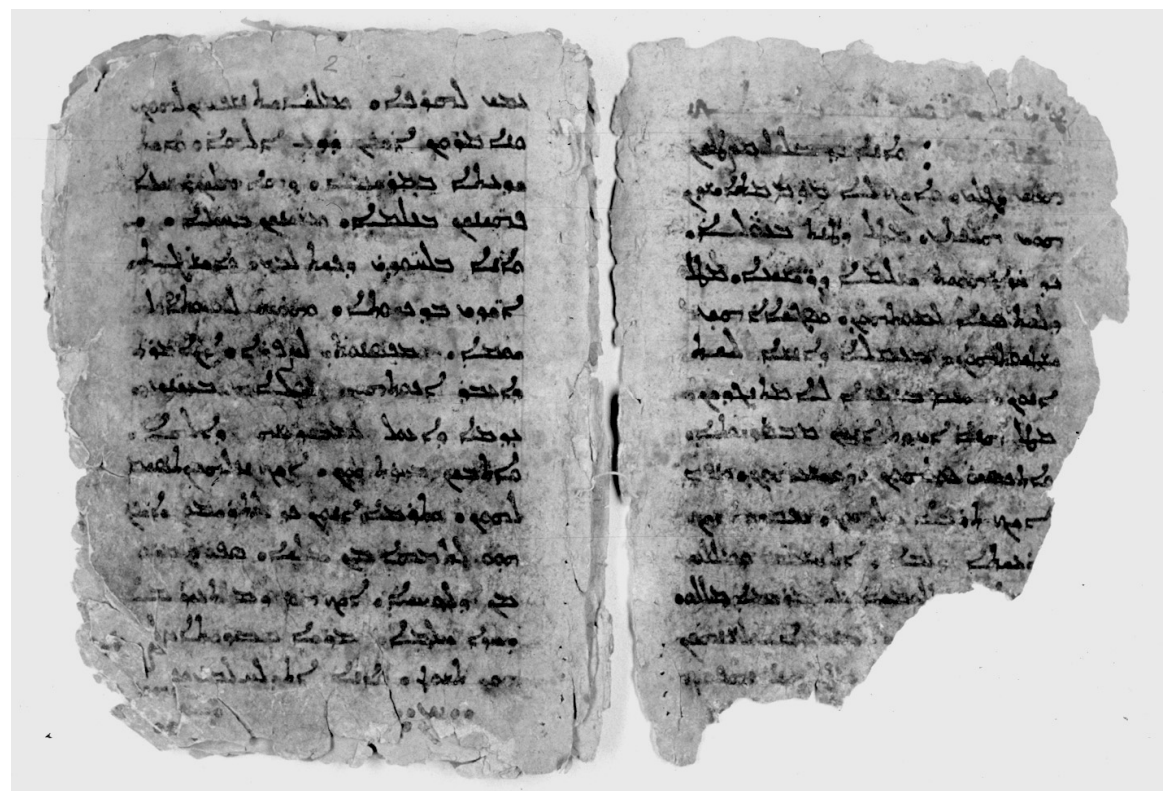

P1. 14.

SyrHT $724 b$ verso 


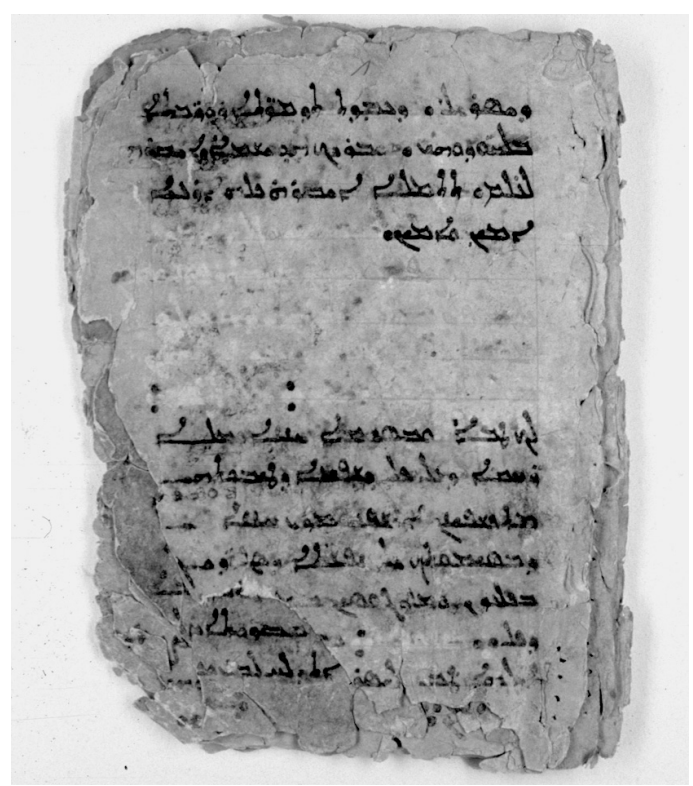

P1. 15.

SyrHT 72 5a recto

\subsection{Manuscript fragments SyrHT 72 and E26: the "double" quire-number on the bottom margin}

With "double" quire-number we mean a quire-number that is repeated twice, in the right corner and in the left corner of the bottom margin, as we have already seen in the manuscript fragments SyrHT 72.

The manuscript fragments E26 $(20.5-21.5 \times 11.5-12.75 \mathrm{~cm})^{56}$ include an anti-Manichaean polemic, a text on omens, and the lives of John of Dailam and St. Serapion with the addition of several unidentified fragments where very few words or few writing lines are attested. The text are in the Sogdian language in East Syriac script.

Sims-Williams assigned to the signature E26 all the fragments written "in a distinctive, very small handwriting" ${ }^{57}$ At the same time, he underlines by quoting Sundermann in turn - that the fragments assigned to E26 probably belong to two different manuscripts because two pages show on the

\footnotetext{
${ }^{56}$ SiMS-WILLIAMS 2012, 80; SIMS-WILLIAMS 2015.

${ }^{57}$ Sims-WiLliams 2012, 80.
} 
verso side the same quire-number. Leaving aside two very small fragments E26/22 and E26/43 ${ }^{58}$ from the bottom margin where is quite impossible to determine whether there is a quire-number or an addition to the text, ${ }^{59}$ the quire-numbers as attested in E26 are the following:

$\mathrm{E} 26 / 3^{60} / \mathrm{v} / \mathrm{w} \mathrm{w}=6$, i.e. the last page of the fifth quire (PI. 16)

In his two recent studies on this fragment, ${ }^{61}$ Sims-Williams clearly asserts that the quire-number $\mathrm{w}=6$ is repeated twice in the bottom margin with decorative pointing. With particular regard to the decorative points, we can add that both quire numbers are enclosed by two horizontal points probably in red ink.

Regarding the quire-number, I have no doubt that the quire-number in the bottom margin on the right side - the one more close to the inner margin is the Syriac letter w. On the other hand, I doubt that the other letter - the one more on the left side - is the same letter, i.e. w. In fact, it seems to me a very similar ductus to that of $\check{z}$ which is, together with $f$ and $x$, one of the characters added by the Sogdian writing system in adopting the 22 letters of the Syriac alphabet.

Moreover, the ductus seems to me very similar to that of the letter $\check{z}$ as attested in the Sogdian word for "life" in the recto of the same fragment; we have žw'n "life" in $/ \mathrm{r} / 6 /$ and žw' ny "from a life" in $/ \mathrm{r} / 13 /{ }^{62}$ (PI. 17)

$\mathrm{E} 26 / 28 \mathrm{~g}^{63} / \mathrm{v} /: \mathrm{w}=6$, i.e. the last page of the fifth quire (PI. 18)

Concerning the decorative pointing, two points probably in red ink are visible before the quire number; the same applies for the one after the quirenumber whereas what follows is missing. Because a very small portion of the fragment has been preserved, it is not possible to determine the correct position of the quire-number on the bottom margin and it is not possible to be sure that the same quire-number was repeated twice.

Because of the fragmentary preservation, I would be careful even to assert that we are certainly dealing with the verso of this fragment. In any case, even if we follow the hypothesis that two manuscripts are involved because

\footnotetext{
${ }^{58}$ E26/22 = n104; E26/43 = n140 respectively. See: http://turfan.bbaw.de/dta/n/dta_n index. html

${ }^{59}$ Sims-Williams 2012, 87, 96.

${ }^{60} \mathrm{E} 26 / 3=\mathrm{n} 145$. The fragment contains a polemic against the Manichaeans.

${ }^{61}$ See Sims-Williams 2012, 81; Sims-WiLliams 2015, 28.

${ }^{62}$ For the text, see Sims-WiLliams 2015, 26-27.

${ }^{63} \mathrm{E} 26 / 28 \mathrm{~g}=\mathrm{n} 114 / 1$. From a literary point of view, the fragment is part of the life of Serapion.
} 
two fragments show the same number on the verso side, the reason for having two different letters - if we accept the proposed reading, and if they are actual quire numbers - on the bottom margin as quire number is not clear. If they are not even quire numbers, it has to be explained what they actually mean. It seems to me that the hand is the same, same for both letters and same for the text, I would exclude that one letter is a later addition.

The preserved fragments do not constitute a bifolium. Therefore, it cannot be a bifolium signature, which seem to be unattested in the Syriac manuscripts anyways. ${ }^{64}$ Could it count as a foliation system at all? Even if so, where would it come from? We have not found any other example in the Christian Sogdian and Syriac manuscript fragments in the Berlin Turfan Collection. Moreover, to the best of my knowledge, we do not have similar system in the Syriac manuscript tradition.

${ }^{64}$ Borbone and Briquel-ChatonNET and BALICKA-WiTAKowSKa 2015, 256. 


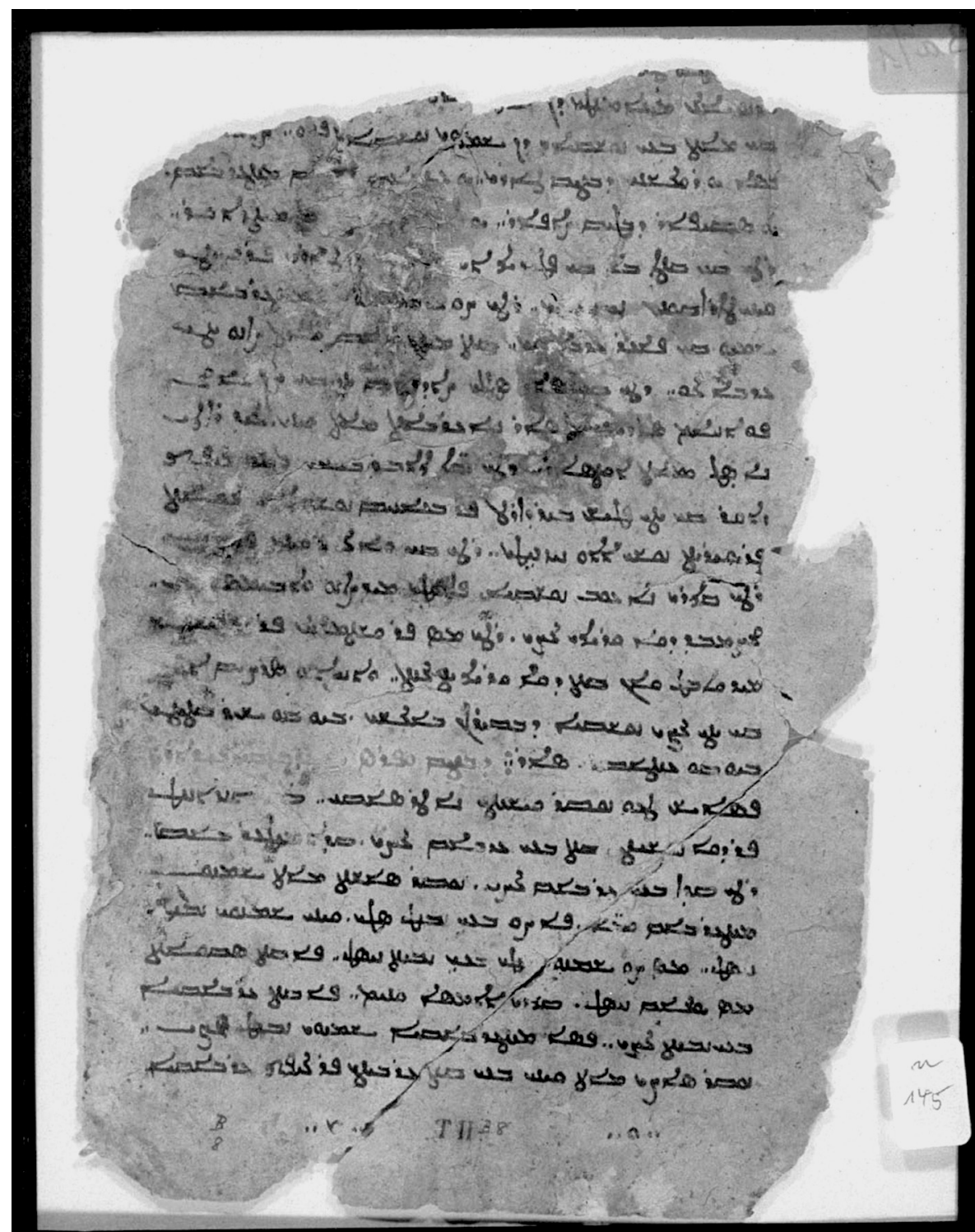

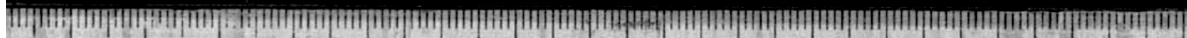

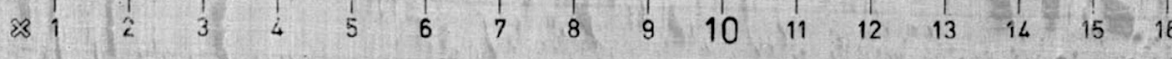

P1. 16.

$\mathrm{E} 26 / 3 / \mathrm{V} /=\mathrm{n} 145$ verso 


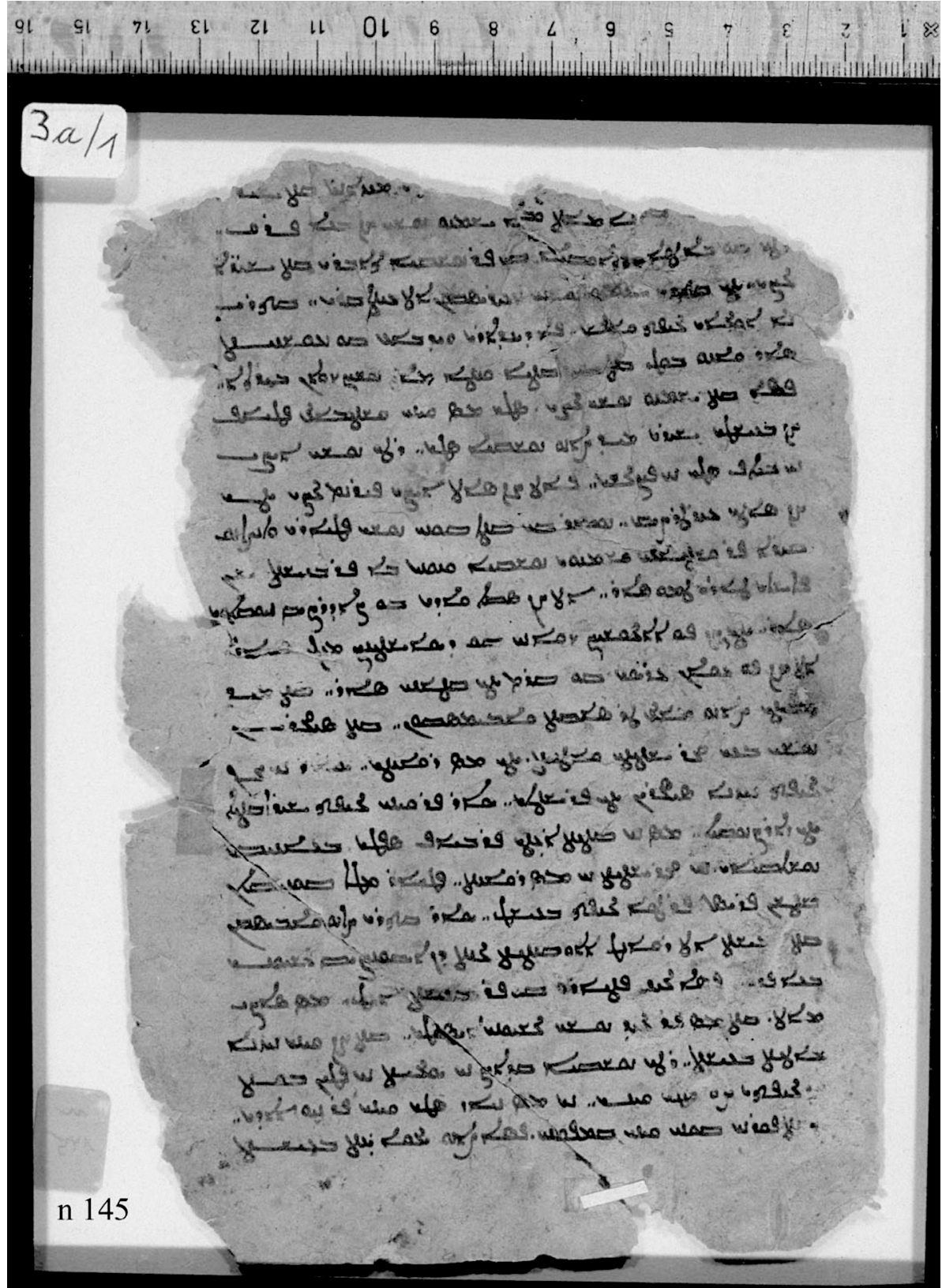

Pl. 17.

$\mathrm{E} 26 / 3 / \mathrm{r} /=\mathrm{n} 145$ recto 


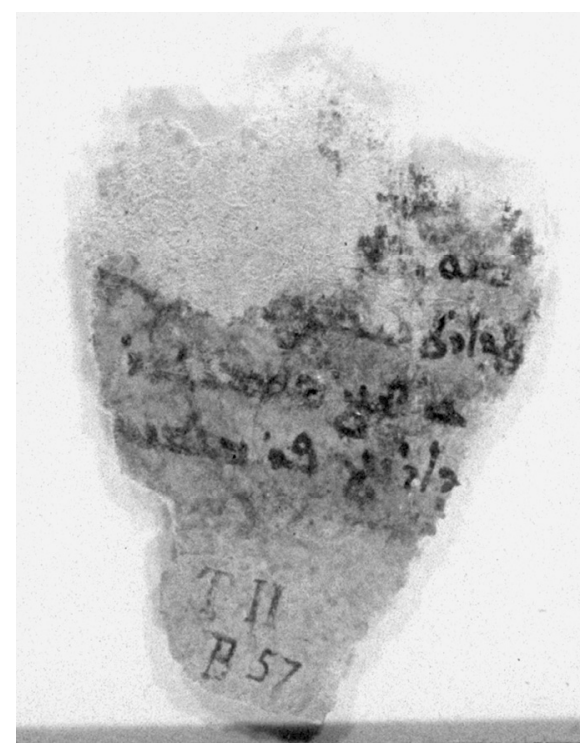

Pl. 18.

$\mathrm{E} 26 / 28 \mathrm{~g} / \mathrm{v} /=\mathrm{n} 114 / 1$ verso

\subsection{The "double" quire-number as attested in the Syriac manuscript fragments from the Krotkov Collection}

In 1996 Meshcherskaya ${ }^{65}$ published an article focused on the literary and material aspects of the Syriac manuscript fragments from the Krotkov Collection and housed at the Institute of Oriental Manuscripts, Russian Academy of Sciences in St. Petersburg. Leaving aside a Syriac fragment found in Astana and already published, ${ }^{66}$ Meshcherskaya takes into account ninety-seven fragments mostly unpublished and not yet studied. The scholar claims that these fragments are from eighteen pages of a manuscript showing "a more or less connected text". ${ }^{67}$ The finding place of the fragments is unknown: that of the Turfan area is assumed because all material belonging to the Krotkov Collection comes from Turfan. Regarding the provenance, Meshcherskaya suggests that the manuscript was composed

${ }^{65}$ MeshCHERSKaya 1996. A special thank to Pavel Lurje and Anton Pirtula for giving me the Russian version of this publication. See MeshCherskaya 1994.

${ }^{66}$ PigulevsKaja 1938; 1940.

${ }^{67}$ MeshCHERSKAYA 1996, 222. 
in Mosul and later brought to Turfan. ${ }^{68}$ Concerning the date, the scholar is inclined to consider the middle of the thirteenth century, the terminus ante quem. ${ }^{69}$

This material is included in the present study as part of an ongoing project that aims at espanding knowledge on the production and the use of the manuscripts - which survive as manuscript fragments - among the Christian communities in early Medieval Turfan. On this occasion, the numbering of the quires as reflected in the Syriac fragments discussed by Meshcherskaya will be discussed. I have recently had the opportunity to look at this material. ${ }^{70}$ Nowadays 116 fragments are preserved in 5 folders $(40 \times 40 \mathrm{~cm})$. The first folder ${ }^{71}$ contains the fragments listed as $1-4$, the second folder ${ }^{72}$ the fragments $5-11$, the third folder ${ }^{73}$ includes the fragments $12-19$, the fourth folder ${ }^{74}$ contains the fragments $20-65$ and the last folder ${ }^{75}$ includes the fragments 66-116 which are very small.

Among the material aspects highlighted by Meshcherskaya, there is the numbering of the quire: "On one of the folios there is a letter tẹt in the lower field, accompanied by an ornamental cross. This letter marks a quire of the manuscript". ${ }^{76}$

The quire-number (PI. 19) is attested on the bottom margin in the fragment 10 which is preserved in the second folder SI 5844 Inv. 5900 L. 2. The quire-number is repeated twice and it is enclosed by decorative pointing: two internal horizontal points in black ink and four points in red ink, one above, one below, one to the right and one to the left of the two internal horizontal points. They form a cross as in the manuscript fragments E27: same decorative pointing, same use of the ink, same position on the bottom margin but different system to mark the quire-number.

\footnotetext{
${ }^{68}$ MESHCHERSKAYA 1996, 225.

${ }^{69}$ MESHCHERSKAYA 1996, 226.

${ }^{70} \mathrm{I}$ would like to express my gratitude to Irina Popova for giving me the permission to check the Syriac fragments from the Krotkov Collection.

${ }^{71}$ SI 5844 Inv. 5900 L. 1.

72 SI 5844 Inv. 5900 L. 2.

${ }^{73}$ SI 5844 Inv. 5900 L. 3.

${ }^{74}$ SI 5844 Inv. 5900 L. 4.

75 SI 5844 Inv. 5900 L. 5.

${ }^{76}$ MESHCHERSKAYA 1996, 223.
} 


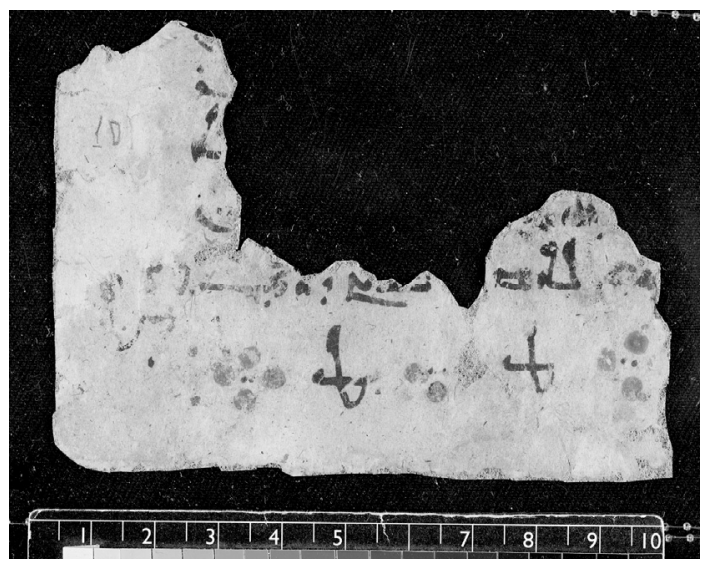

Pl. 19.

Fr. 10 SI 5844 Inv. 5900 L. 2

Concerning fragment 10 from the Krotkov Collection, I would suggest that it is a "double" quire-number excluding the hypothesis of a quirenumber extended across the bottom margin. Only the lower part of the fragment has survived. According to me, the width of the fragment is $9.6 \mathrm{~cm}$, the width of the written area is $7.3 \mathrm{~cm}$ and the outer margin is $2.3 \mathrm{~cm}$. Where it is possible to measure the width of the manuscript ${ }^{77}$ it is circa $11 \mathrm{~cm}$ and the inner margin is circa $0.5 \mathrm{~cm}$. Considering that usually the quire-number is attested within the written area, I think that only the inner margin is missing. Therefore, I would suggest it to be a "double" quire-number.

\subsection{Manuscript fragments E28, E29, SyrHT 194-SyrHT 195: quire-number on the bottom margin in central position}

While listing a group of fragments as the manuscript fragments E28, SimsWilliams pointed out on the one hand that they may belong to different manuscripts because some pages have different sizes, and on the other hand that they share many formal features such as the hand, verso-mark, quire-numbers, titles, headings, punctuation and pointing. ${ }^{78}$ Of course, this issue needs to be clarified by further studies. For the moment - as a first overview - we will follow the classification adopted by Sims-Williams in his catalogue.

${ }^{77}$ For instance fragment 8, SI 5844 Inv. 5900 L. 2. With particular regard to the dimension of the manuscript, Meshcherskaya speaks of circa10×7 cm. See MESHCHERSKAYA 1996, 222.

${ }^{78}$ Sims-WilLiams 2012, 127. 
From a literary point of view, E28 is an example of a monastic miscellany or monastic multiple-text manuscript as the manuscript fragments E27. It is written in the Sogdian language in East Syriac script and it includes lives of saints, commentaries, homilies, and general ascetical literature as well as unidentified texts.

The attested quire-numbers are: $:^{79}$

$\mathrm{E} 28 / 12^{80} / \mathrm{r} /: \mathrm{yt}=19$, i.e. the first page of the nineteenth quire (PI. 20)

The fragment is lost and we only have a photo reproduction. It seems that the quire-number on the bottom margin is not exactly in the middle but towards the inner margin. It seems that the quire-number has no decorative punctuation point.

$\mathrm{E} 28 / 19 \mathrm{~b}^{81} / \mathrm{v} /: \mathrm{y}[]=.10[$.$] , i.e. the last page of the tenth(?) quire (PI. 21)$

Only a portion of the fragment is preserved. Therefore, with particular regard to the quire-numbers and its decoration, only the letter y in black ink and two decorative horizontal points in black ink are recognizable.

The manuscript fragments known as E29 ${ }^{82}$ show the same problems as the previous text. We thus need further studies to establish if the eight pages grouped by Sims-Williams as E29 are all part of the same manuscript or not. ${ }^{83}$ For the moment, we follow the classification adopted by Sims-Williams in his catalogue.

Concerning literary aspects, E29 is a monastic miscellany or monastic multiple-text manuscript as the manuscript fragments E27 and E28. It contains the stories of Moses, David, Daniel, the martyrdom of Cyriacus and Juditta, a homily on fasting and a text on the encounter between Simon Peter and on Simon Magus. The text is written in the Sogdian language in East Syriac script.

Only one quire-number is attested:

$\mathrm{E} 29 / 5^{84} / \mathrm{r} / \mathrm{:} \mathrm{w}=6$, i.e. the first page of the sixth quire (PI. 22)

The quire-number is placed in the middle of the bottom margin. We would need physical analysis for establishing the ink used the quire-number. The quirenumber is enclosed by two decorative rhombs of four dots. The two horizontally opposed dots are in red ink and those vertically opposed are in black ink.

\footnotetext{
${ }^{79}$ Concerning the small fragments E28/80, E28/90 and E28/122 see note 15.

${ }^{80} \mathrm{E} 28 / 12=\mathrm{n} 529^{*}$. See: http://turfan.bbaw.de/dta/n/Konkordanz_n_verloren.pdf. The fragment measures $28.5 \times 20.5 \mathrm{~cm}$ and its content is about the ascetic life. See SIMS-WILLIAMS 2012, 134-135.

${ }^{81} \mathrm{E} 28 / 19 \mathrm{~b}=\mathrm{n} 367$. The dimensions of the fragment are $15 \times 8.5 \mathrm{~cm}$ and the text is focused on the ascetic life. See Sims-Williams 2012, 138.

${ }^{82}$ SiMS-WILLIAMS 2012, 168.

${ }^{83}$ Sims-WiLLiAMS 2012, 165.

${ }^{84} \mathrm{E} 29 / 5=\mathrm{n} 196$. The fragment measures $22 \times 15.5 \mathrm{~cm}$ and the text consists of a homily on fasting. SiMS-WILLIAMS 2012, 167.
} 


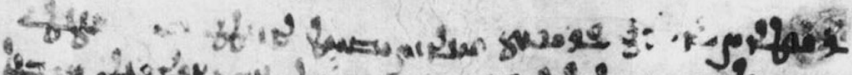

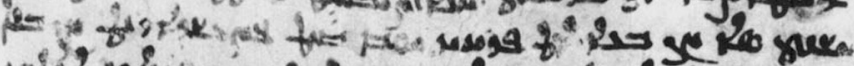

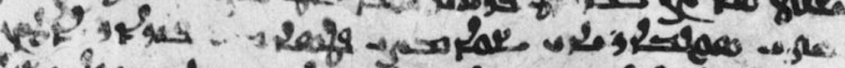

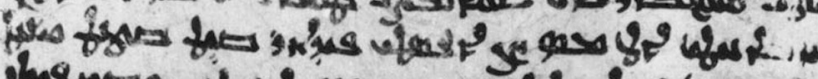

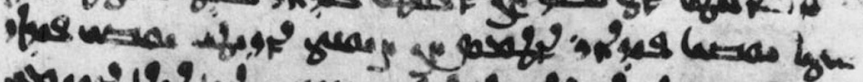

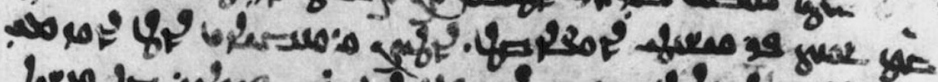

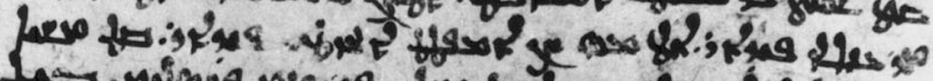

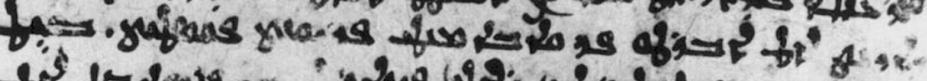

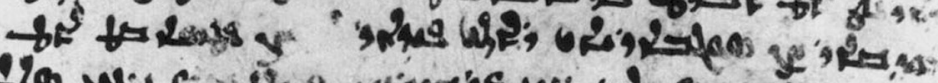

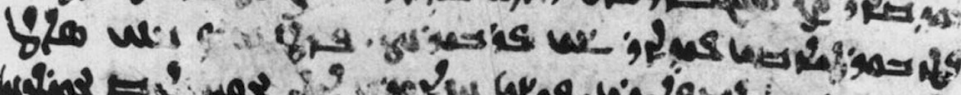

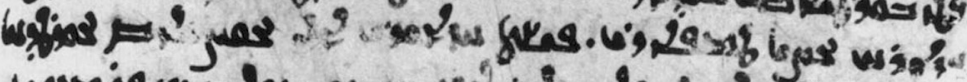

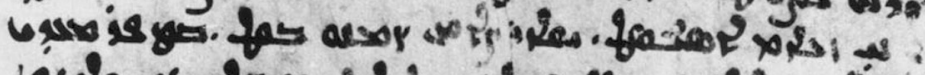

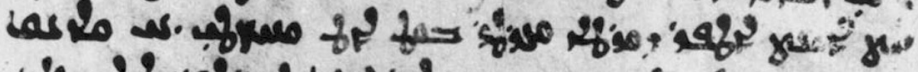

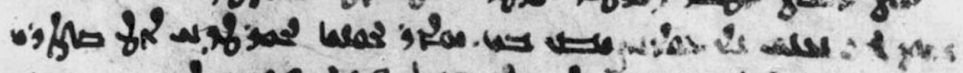

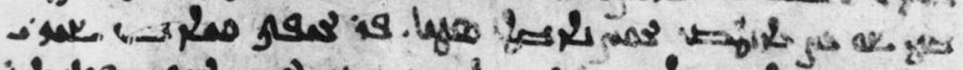

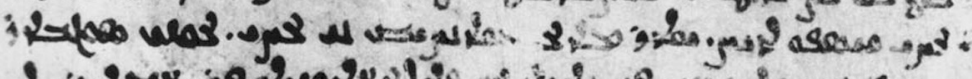

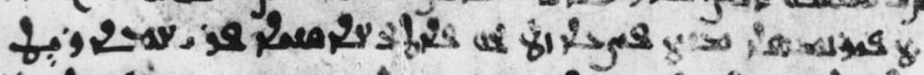

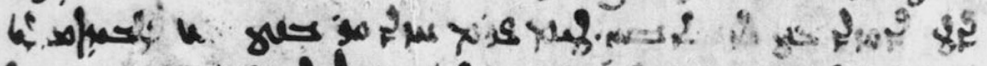

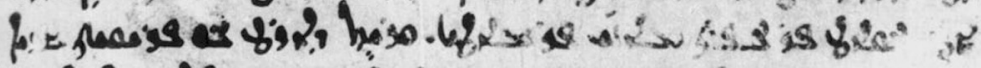

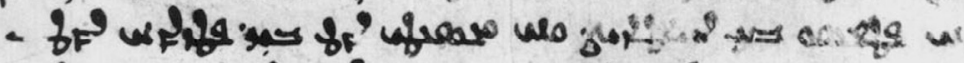

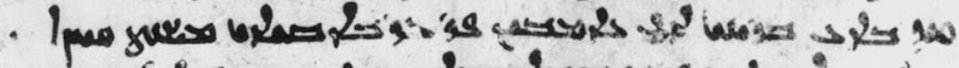

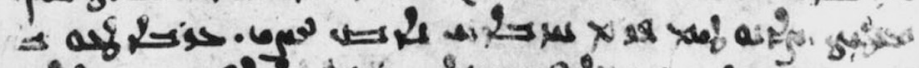

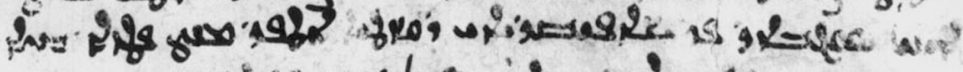

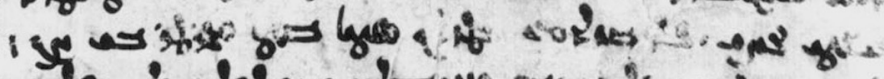

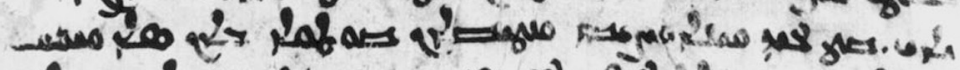

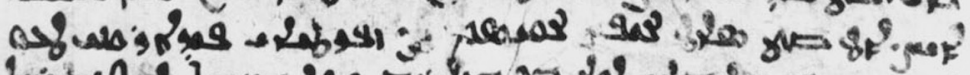

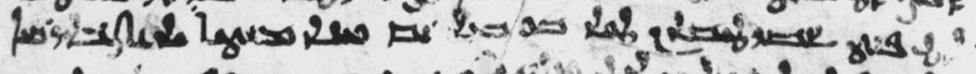

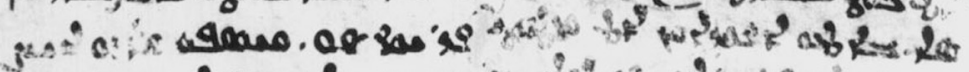

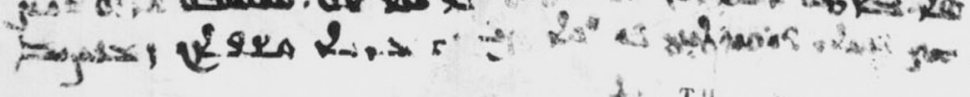




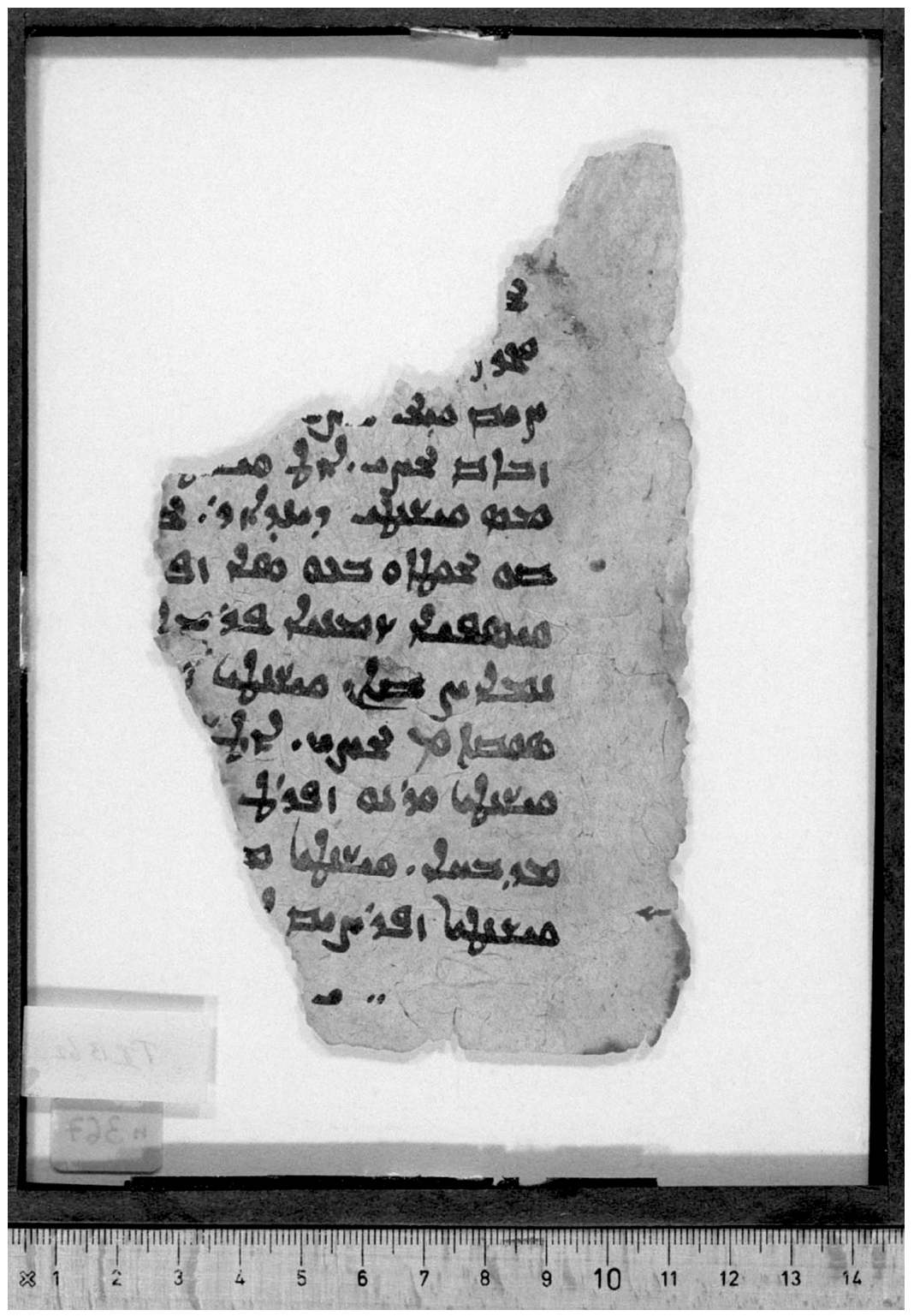

P1. 21.

$\mathrm{E} 28 / 19 \mathrm{~b} / \mathrm{v} /=\mathrm{n} 367$ verso 


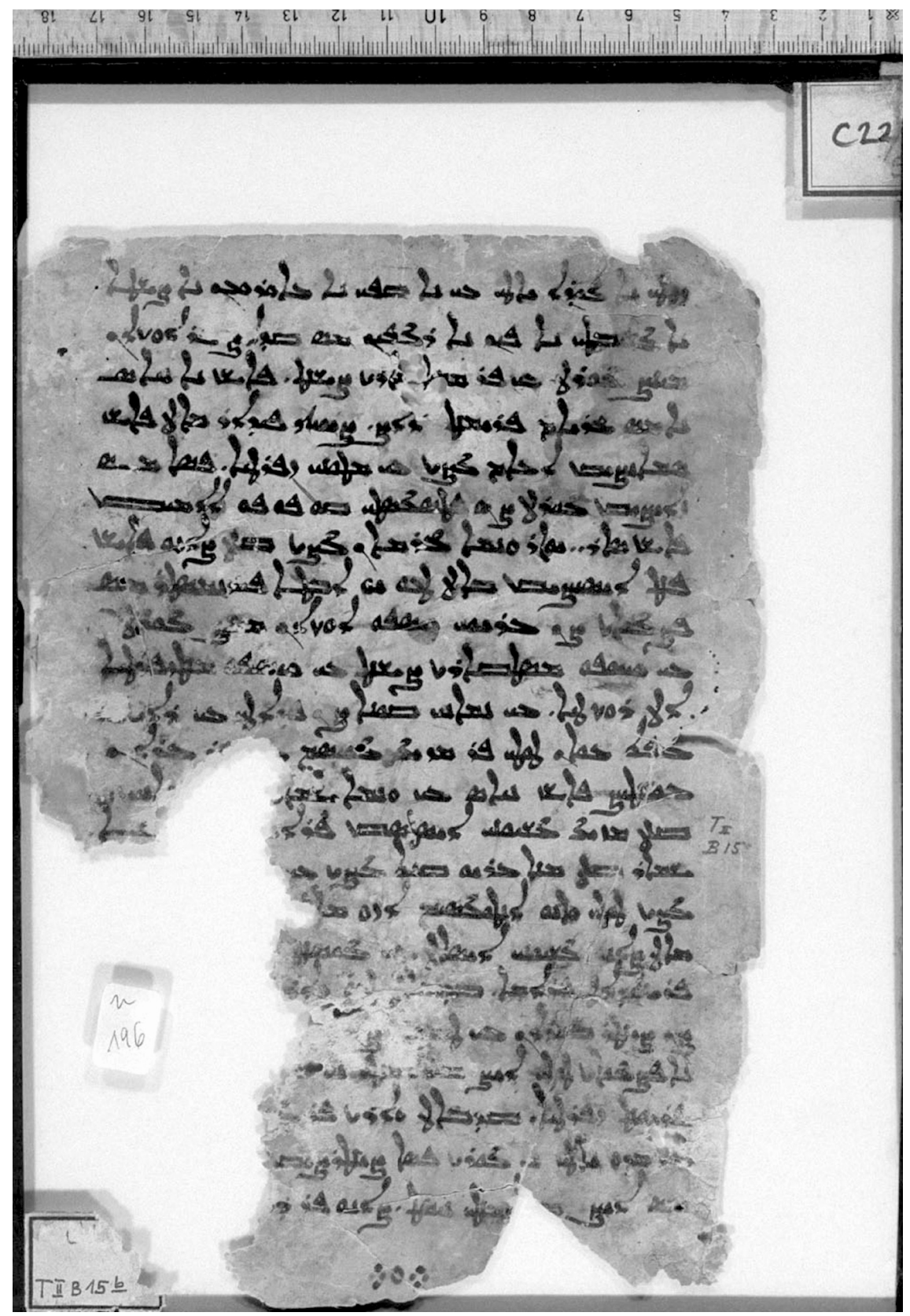

P1. 22.

$\mathrm{E} 29 / 5 / \mathrm{r} /=\mathrm{n} 196$ recto 
The fragments SyrHT 194-SyrHT 195 together with the fragments SyrHT 109 and SyrHT 110 belong to the same manuscript. Concerning textual genre, they are grouped as Taksa A within the liturgical texts by HunterDickens. ${ }^{85}$ The text is written in the Syriac language in East Syriac script. The quire-numbers attested are:

SyrHT 194b: ${ }^{86} \mathrm{~d}=4$, i.e. the last page of the fourth quire (PI. 23).

The fragment measures $15.1 \times 13.7 \mathrm{~cm} .{ }^{87}$ Even if a portion of the inner margin and circa the half of the bottom margin is missing, we can see that the quire-number is in the middle of the bottom margin. As for all other cases discussed in this article, the quire-number and the main text have been written by the same hand. Without physical analysis is not possible to establish if the ink used for the quire-number as well as for the text is brown or faded black. The quire-number is enclosed by decorative pointing: two internal horizontal point in brown or faded black ink with three points in red ink, one above, one below and one to the outer side of the two internal horizontal points. ${ }^{88}$

SyrHT $195 \mathrm{~b}:{ }^{89} \mathrm{~h}=5$, i.e. the last page of the fifth quire (PI. 24).

The dimensions of the fragment are $11.5 \times 13.6 \mathrm{~cm}$. The bottom margin is entirely preserved and the central position of the quire-number is clearly visible. Concerning the hand, the ink and the decorative pointing, it is the same as for the fragment SyrHT 194.

${ }^{85}$ HunTER and DiCKENS 2014, 123-125; 197-198; 452.

${ }^{86} \mathrm{~b}$ meaning verso. See HUNTER and DiCKENS 2014, 197.

${ }^{87}$ HUNTER and DICKENS 2014, 197.

${ }^{88}$ In the manuscript fragments E27 we have four point in red ink instead of three, as we have already seen.

${ }^{89}$ b meaning verso. See HUNTER and DiCKENS 2014, 198. 


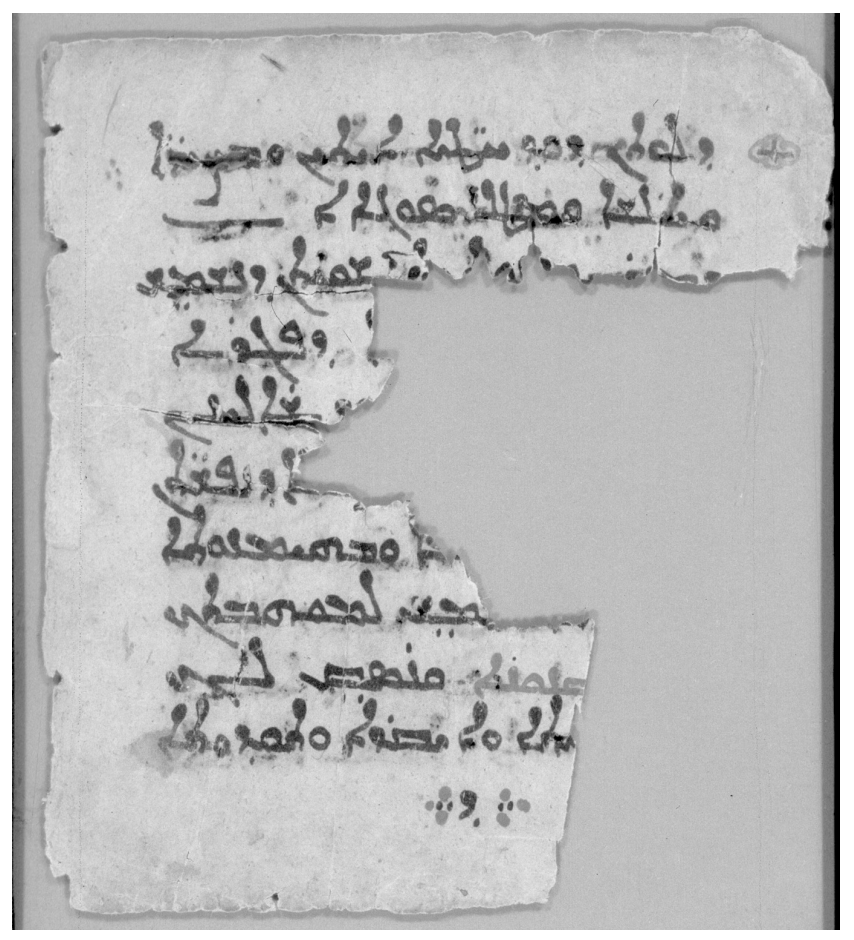

P1. 23.

SyrHT 194b verso

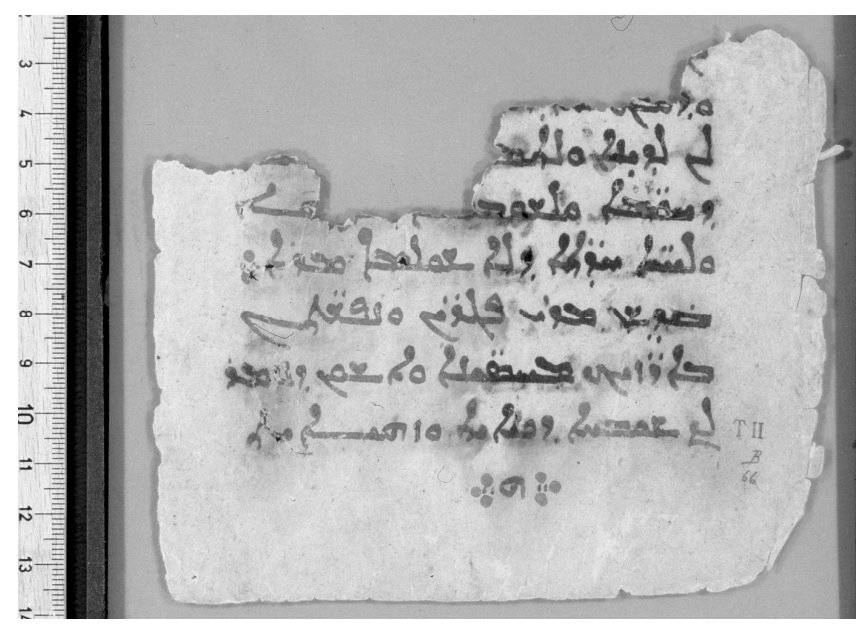

P1. 24.

SyrHT 195b verso 


\subsection{SyrHT300 and E44/MIK III 45: two cases per $\mathrm{se}^{90}$}

According to Hunter and Dickens, ${ }^{91}$ the fragment SyrHT 300 together with the fragments SyrHT 241, SyrHT 277 and n327 forms an almost entire page. From a literary point of view, we are dealing with a Syriac lectionary ${ }^{92}$ in East Syriac script.

The quire-number in the fragment SyrHT $300(5.6 \times 7.2 \mathrm{~cm})^{93}$ would be:

SyrHT $300 \mathrm{~b}:{ }^{94} \mathrm{~g}$ or $t=3$ or 9 , i.e. the first page of the third or of the ninth quire.

So far we can see, it is very difficult to give a sure reading of the quirenumber. Part of the decorative pointing of the quire-number is clearly visible. It consists of two horizontal points in black ink with four points in red ink, one above, one below, one to the right and one to the left of the two internal horizontal points.

The position of the quire-number is very unusual. If we follow Hunter and Dickens $^{95}$ we have a quire-number on the upper margin. Following this hypothesis, this would be the only evidence of a quire-number on the upper margin as attested in the Syriac and Christian Sogdian fragments from the Berlin Collection. To the best of my knowledge, this would be a rare, if not unique, feature even if we consider the entire Syriac manuscript tradition not only that from Turfan. One might recall once again the most update survey on Syriac manuscripts where we do not find any example of a quire-number on the upper margin. ${ }^{96}$ The other possibility is that $g$ or $t$ is not a quirenumber.

I am more inclined to consider $\mathrm{g}$ or $\mathrm{t}$ as a marginalia indicating a new section in the text. This kind of marginalia is attested in the Christian manuscript fragments from Turfan. Recently, Dickens discusses the marginalia in the Syriac fragment SyrHT $123 .{ }^{97}$ He explains the presence of $\mathrm{g}$ as a typical marginalia "used to alert the reader to new sections in the text,

\footnotetext{
${ }^{90}$ Both manuscript fragments are available online at http://idp.bl.uk/.

${ }^{91}$ HunTER and Dickens 2014, 235; 262-263; 391-392.

${ }^{92}$ It is listed as lectionary B by HuNTER and DiCKENS 2014, 448.

${ }^{93}$ HuNTER and DiCKENS 2014, 282.

${ }^{94}$ b meaning recto. See HUNTER and DICKENS 2014, 282.

${ }^{95}$ HUNTER and DiCKENS 2014, 282.

${ }^{96}$ Borbone and Briquel-ChatonNeT and BALICKA-WiTAKOWSKA 2015, 256.

${ }^{97}$ DiCKENS 2013, 11.
} 
particularly in the biblical or liturgical texts" clarifying that "these biblical sections do not correspond to the chapter divisions familiar to most Western readers". ${ }^{98}$ The decorative pointing is the same of SyrHT 300. The position differs: outer margin for g in SyrHT 123 and upper margin for SyrHT 300. The almost entire page including SyrHT 300 is still unpublished. According to Hunter and Dickens, ${ }^{99}$ the publication is in preparation, and, surely, it will help in settling the matter.

The Syriac manuscript MIK III 45 consists of 61 pages and measures $22.5 \times 14 \mathrm{~cm} .{ }^{100}$ It is also included in the catalogue of the Christian Sogdian manuscript fragments and listed under the heading E44 because it contains few lines in Sogdian in East Syriac script as well as in Sogdian script. ${ }^{101}$ Concerning the text genre, the manuscript MIK III 45 is a service-book. A very accurate and comprehensive study on MIK III 45 has been published in 2017. ${ }^{102}$ Among the material aspects, the structuring and the numbering of the quires have been discussed and we remind to this important publication for any detail. For our purposes, worth highlighting is the presence of the quire-numbers (', p, s, q) in the middle of a black page with no decoration; the different hand between the main text and the quire-number; and, finally, the upside-down writing for the quire-numbers ' in MIK III 4523 verso and for the quire-number $\mathrm{p}$ in MIK III 4537 verso. ${ }^{103}$

The manuscript MIK III 45 shows a completely different scenario. Interesting enough, by combining literary and material aspects, Hunter and Coakley propose Merv and not Turfan as the place of provenance of the manuscript MIK III $45 .^{104}$

\section{Conclusions}

Our impression is that if we look at the quire numbering system as attested in the manuscript fragments found in Turfan, instead of representing a standard Syriac system, they show the existence of different systems which in turn also imply different proveniences. Almost every single less-fragmen-

\footnotetext{
${ }^{98}$ DiCKENS 2013, 11.

${ }^{99}$ HuNTER and DiCKENS 2014, 282.

${ }^{100}$ HUNTER and DiCKENS 2014, 346-351.

${ }^{101}$ Sims-Williams 2012, 190.

${ }^{102}$ HUNTER and COAKLEY 2017.

${ }^{103}$ See http://idp.bl.uk/.

${ }^{104}$ HunTER and DiCKENS 2017, 1-60; 273-280.
} 
tary manuscript shows a different way of indicating the numeration of pages. An alternative scenario in which those differences could be related to multiple actors in a place of manuscript production (scribe, book binder etc.) is difficult to imagine in the specific context of Turfan. In contrast with other religions attested at Turfan - Manicheism, Buddhism -, Christianity never had an official status, and this seems to be reflected in manuscript production. The alleged monastery and the hypothetical remains of a church (which, like Bulayïq, have not yet been archaeologically studied) are the only known material witnesses of Christianity in the oasis of Turfan, besides of course the manuscript fragments. One must also keep in mind in all examples analysed here (with the exception of MIK III 45) that the main text and the quire numbers were written by the same hand (though we are still at the initial stages of paleographical studies of these fragments). This supports the hypothesis of Dickens ${ }^{105}$ of a small community, or small communities, which arrive at the oasis of Turfan during a period of affirmation of other religions in the East and in the West. He links the origins of the Christian communities in Turfan with religious persecution in Tang China to the East, and the Islamic conquest of Central Asia in the West. Under these circumstances, the most plausible explanation for the extreme differentiation of the system of numbering of quires would be the diversity of provenience of manuscripts rather than a purely local production.

\section{Abbreviations}

Pl. = Plate

\section{References}

Andrist, Patrick and CANART, Paul and ManiaCi, Marilena 2013: La syntaxe du codex. Essai de codicologie structurale. Turnhout.

BARBATI, Chiara 2015: "Syriac into Middle Iranian: A Translation Studies Approach to Sogdian and Pahlavi Manuscripts within the Church of the East". In Translation Techniques in the Ancient and Oriental Cultures. Ed. by Artemij Keidan. Open Linguistics, 1 (2015), De Gruyter Open, pp. 444-457, http://degruyteropen.com/ttaoc/.

BARBATI, Chiara 2015a: "La documentation sogdienne chrétienne et le monastère de Bulayïq". In Le christianisme syriaque en Asie centrale et en Chine. Ed. by Pier Giorgio Borbone and Pierre Marsone. Paris: Geuthner 89-120.

Barbati, Chiara 2015 [2014]: "Codicological issues in exploring the Christian Sogdian manuscript fragment tradition”. In Gazette du livre médiéval, 61, 20-35.

\footnotetext{
${ }^{105}$ DiCKENS 2013, 3-4.
} 
BARBATI, Chiara 2016: The Christian Sogdian Gospel Lectionary E5 in Context, Veröffentlichungen zur Iranistik, 81, Wien.

BARBATI, Chiara 2017: "Mitteliranisch-christliche Manuskriptologie". In Handbuch Iranistik, 2. Ed. by Ludwig Paul. Wiesbaden, 403-411.

Bausi, Alessandro and Borbone, Pier Giorgio et al. (eds.) 2015: Comparative Oriental Manuscript Studies. An Introduction. Hamburg.

Borbone, Pier Giorgio and Briquel-Chatonnet, Françoise and BAlickA-WitAkowska, Ewa 2015: "Syriac codicology". In Comparative Oriental Manuscript Studies. An Introduction. Ed. by Alessandro Bausi and Pier Giorgio Borbone et al.. Hamburg, 252-266.

BriQuel-Chatonnet, Françoise and Debié, Muriel (eds.) 2015: Manuscripta Syriaca. Des sources de première main. Cahiers d'études syriaques, Paris: Geuthner.

BuzI, Paola 2016: "From Single-Text to Multiple Text Manuscripts: Transmission Changes in the Coptic Literary Tradition. Some Case-Studies from the White Monastery Library". In One-Volume Libraries: Composite and Multiple-Text Manuscripts. Ed. by Michael Friedrich and Cosima Schwarke. Studies in Manuscript Cultures, De Gruyter, 93-109.

Desreumaux, Alain 2015: "Christian Palestinian Aramaic manuscripts". In Comparative Oriental Manuscript Studies. An Introduction. Ed. by Alessandro Bausi and Pier Giorgio Borbone et al. Hamburg, 132-136.

Dickens, Mark 2013: "Scribal Practices in the Turfan Christian Community". In Journal of the Canadian Society for Syriac Studies, 13, 3-28.

Dickens, Mark 2013a: "The Importance of the Psalter at Turfan". In From the Oxus River to the Chinese Shores. Studies on East Syriac Christianity in China and Central Asia. Ed. by Li Tang and Dietmar Winkler. Wien, 357-380.

Friedrich, Michael and Schwarke, Cosima (eds.) 2016: in One-Volume Librarires: Composite and Multiple-Text Manuscripts. Studies in Manuscript Cultures, De Gruyter.

Hatch, William H.P. 1946: An Album of Dated Syriac Manuscripts. Boston: The American Academy of Arts and Sciences.

Hunter, Erica C.D. and CoAKley, James F. 2017: A Syriac Service-Book from Turfan. Museum für Asiatische Kunst, Berlin MS MIK III 45, Berliner Turfantexte, 39, Turnhout.

HunTER, Erica C.D. and Dickens, Mark 2014: Syriac Texts from the Berlin Turfan Collection. Verzeichnis der orientalischen Handschriften in Deutschland, 5,2, Stuttgart.

Kessel, Grigory 2014: "Syriac monastic miscellanies". In Comparative Oriental Manuscript Studies. An Introduction. Ed. by Alessandro Bausi and Pier Giorgio Borbone et al. Hamburg, 411-414.

MANIACI, Marilena 2015: "Codicology”. In Comparative Oriental Manuscript Studies. An Introduction. Ed. by Alessandro Bausi and Pier Giorgio Borbone et al. Hamburg, 69-88.

MESHCHERSKAYA, Elena N. 2014: "Fragmenty sirijskoj rukopisi iz sobraniya instituta vostokovedeniya ran".

MeshChersKaya, Elena N. 2016: "The Syriac fragments in the N.N. Krotkov Collection". In Turfan, Khotan and Dunhuang. Ed by Ronald E. Emmerick and Werner Sundermann and Ingrid Warnke and Peter Zieme. Berlin, 221-227.

PigulevskAJA, Nina V. 1938: "Fragments syriaques et syroturcs de Hara-Hoto et de Tourfan". In Revue de l'Orient chrétien, 30, 3-46.

Pigulevskaja, Nina V. 1940: "Sirijskie i-siro tjurkskij fragment iz Chara-Choto i Turfana". In Sovetskoe vostokovedenie, 1, 212-234. 
PIRTEA, Adrian 2018: "Book Review. Chiara Barbati. The Christian Sogdian Gospel Lectionary E5 in Context, Veröffentlichungen zur Iranistik, 81, 2016, Wien”. Iran and the Caucasus, 111-115.

Sims-Williams, Nicholas 1985: The Christian Sogdian Manuscript C2. Berliner Turfantexte, 12 , Berlin.

Sims-Williams, Nicholas 1992: "Sogdian and Turkish Christians in the Turfan and Tunhuang Manuscripts". In Turfan and Tun-huang: the texts. Encounter of civilizations of the Silk route. Ed. by Alfredo Cadonna. Firenze, 43-61.

Sims-Williams, Nicholas 2004: "A Greek-Sogdian Bilingual from Bulayïq”. In La Persia e Bisanzio. Atti del convegno dei Lincei, 201, Roma, 623-631.

Sims-Williams, Nicholas 2012: Iranian Manuscripts in Syriac Script in the Berlin Turfan Collection. Verzeichnis der orientalischen Handschriften in Deutschland, 18,4, Stuttgart.

Sims-Williams, Nicholas 2015: The Life of Serapion and other Christian Sogdian texts from the manuscripts E25 and E26. Berliner Turfantexte, 35. Turnhout.

SundermanN, Werner 1975: "Nachlese zu F.W.K. Müllers "Soghdischen Texten I"”. Altorientalische Forschungen, 3, 85-90.

\section{List of the above mentioned manuscript fragments:}

P1. 1: $\mathrm{E} 5 / 41 / \mathrm{r} /=\mathrm{n} 500 *$ recto

P1. 2: $\mathrm{E} 5 / 51 / \mathrm{r} /=\mathrm{n} 154$ recto

Pl. 3: $E 5 / 91 / r /=n 162$ recto

Pl. 4: $\mathrm{E} 5 / 100 / \mathrm{v} /=\mathrm{n} 160$ verso

Pl. 5: $E 5 / 101 / r /=n 161$ recto

Pl. 6: $\mathrm{E} 27 / 31 / \mathrm{r} /=\mathrm{n} 520 *$ recto

P1. 7: $\mathrm{E} 27 / 51 \mathrm{c} / \mathrm{r} /=\mathrm{n} 494$ recto

P1. 8: $\mathrm{E} 27 / 60 / \mathrm{v} /=\mathrm{n} 489$ verso

P1. 9: E27/61/r/= n 493 recto

Pl. 10: $\mathrm{E} 27 / 127 / \mathrm{v} /=$ n 36 verso

Pl. 11: SyrHT 72 1a recto

Pl. 12: SyrHT 72 2a recto

Pl. 13: SyrHT 72 3a recto

Pl. 14: SyrHT 72 4b verso

Pl. 15: SyrHT 72 5a recto

Pl. 16: E26/3 /v/ = n145 verso

P1. 17: $\mathrm{E} 26 / 3 / \mathrm{r} /=\mathrm{n} 145$ recto

Pl. 18: E26/28g/v/ = n114/1 verso

Pl. 19: Fr. 10 SI 5844 Inv. 5900 L. 2

P1. 20: $\mathrm{E} 28 / 12 / \mathrm{r} /=\mathrm{n} 529^{*}$ recto

P1. 21: E28/19b $/ \mathrm{v} /=$ n367 verso

P1. 22: $\mathrm{E} 29 / 5 / \mathrm{r} /=\mathrm{n} 196$ recto

Pl. 23: SyrHT 194b verso

Pl. 24: SyrHT 195b verso 
I would like to express my deepest gratitude to Irina Popova and the Institute of Oriental Manuscripts, Russian Academy of Sciences in St. Petersburg for allowing the reproduction of the unpublished fragment Fr. 10 SI 5844 Inv. 5900 L.2 (Pl. 19).

I wish to thank the Berlin-Brandenburgische Akademie der Wissenschaften for allowing the reproduction of the manuscript fragments (Pl. 1-18, Pl. 20-24) in the depositum of the Berlin-Brandenburgische Akademie der Wissenschaften in the Staatsbibliothek zu Berlin -Preußischer Kulturbesitz Orientabteilung. 